\title{
An Annotated Bibliography of te reo material held in the Hocken Manuscript and Archives Collection
}

$$
\text { by }
$$

\section{Edith Lorraine Johnston}

\author{
Submitted to the School of Information Management, \\ Victoria University of Wellington \\ in partial fulfillment of the requirements for the degree of \\ Master of Library and Information Studies
}




\section{Acknowledgements}

I te tuatahi ka mihi atu nei au ki ngā iwi o ngā hau e whā nō rātou nei ēnei taonga tuku iho e whakaaturia nei. Ko te tūmanako, mā ēnei paku mahi nāku ka ngawari atu te kite i ngā rauemi nei e tuhia ai i te reo rangatira nei. Nō reira rā, kia mihia kia tangihia rātou ngā kaituhi kua ngaro ki te pō, kia ea ai te wāhanga ki a rātou. Āpiti hono, tātai hono rātou ki a rātou, tātou te hunga ora ki a tātou. Nō reira, tēnā rā koutou.

I thank my supervisor, Alastair Smith for his patient support and guidance and his succinct and helpful comments. I also thank the staff of the Hocken Collections for their untiring support of the project, and in particular Anna Blackman, Curator of Archives for proof reading my first draft. It should be noted however, that any errors or omissions are my responsibility alone. Heartfelt thanks also to the staff of the reference department at the University of Otago library for their support.

Finally, but by no means least, I thank my long-suffering son, Nick, who has done without his mother's company on many occasions, and put up with numerous scratch meals, often well past normal mealtimes. He has seldom complained and has often encouraged me. Thanks, Nick, without your support this would never have happened. 


\section{Table of Contents}

\section{Part A: Bibliographic Plan}

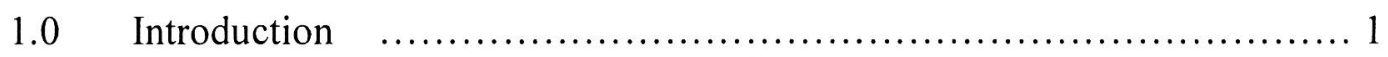

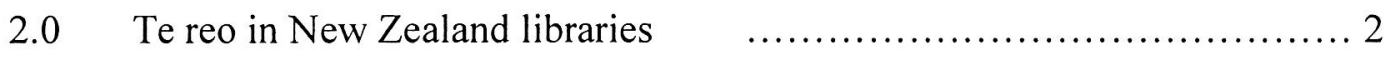

$2.1 \quad$ Aotearoa/New Zealand $\quad$.................................. 2

2.2 Some Indigenous comparisons $\quad \ldots \ldots \ldots \ldots \ldots \ldots \ldots \ldots \ldots \ldots$

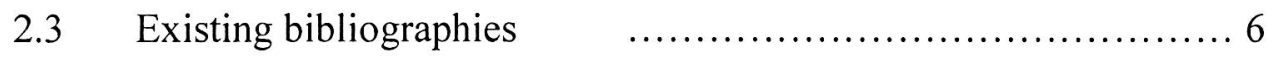

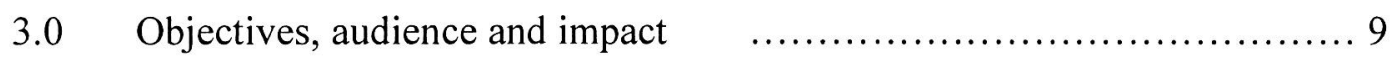

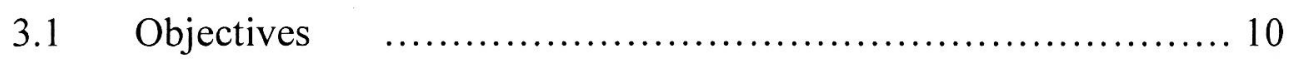

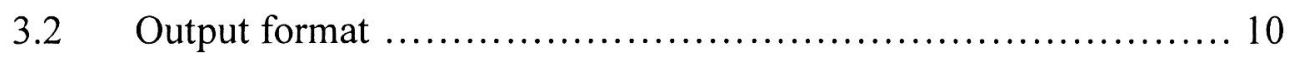

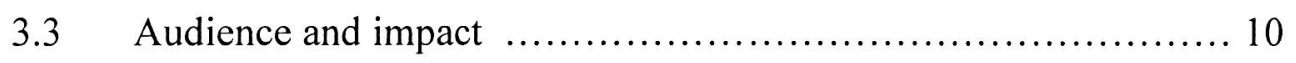

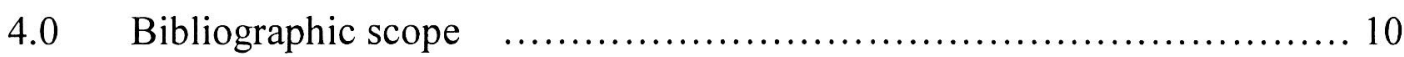

4.1 Subject coverage and limitations $\quad \ldots \ldots \ldots \ldots \ldots \ldots \ldots \ldots \ldots \ldots \ldots$

4.2 Location $\quad$.......................................... 12

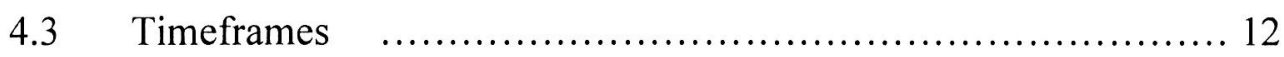

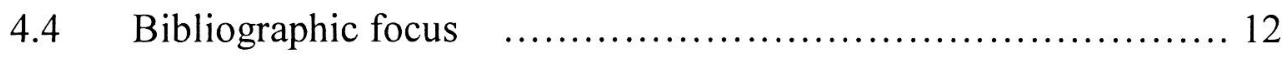

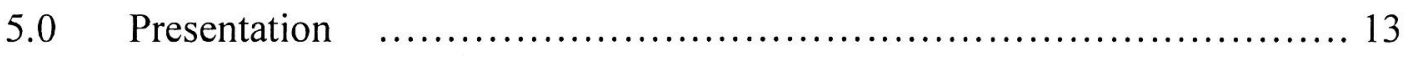

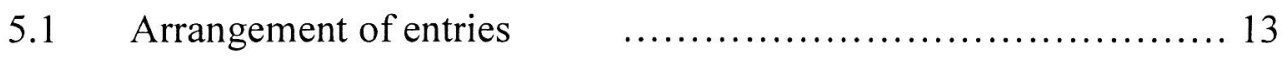

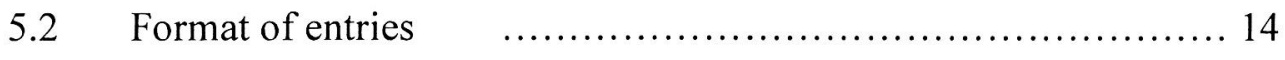

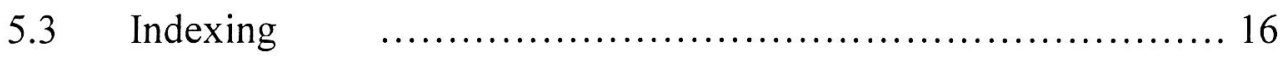

6.0 Future development of the bibliography $\quad$........................... 16 
7.0 Bibliography to Part A

Part B: The Bibliography

Section 1: The Shortland Collection 18

Section 2: MS1166 Collection 36

Section 3: The Beattie Collection 41

Section 4: The Roberts Collection 46

Section 5: The Chapman Collection 52

Section 6: The Wallscott Collection 56

Section 7: Miscellaneous items 61

\section{Appendices}

Keyword index 72

Iwi/hapū index 74 


\begin{abstract}
The Hocken Collections, and in particular the Hocken Archives, have a large number of items, both published and unpublished, either written in te reo or relating to it. Many of these items would hold considerable interest for students of te reo, but are inadequately described in catalogues, making efficient access very difficult. Access to the published grammars and wordlists is facilitated through the University of Otago Library catalogue, but identifying the unpublished material written in, or concerning, te reo is more difficult. Manuscripts and archives are listed in a database, called Hākena, but being an archival database it does not often provide the sort of information people looking for te reo material might be seeking. The aim of this bibliography is to improve access to information on the te reo content of manuscripts held at the Hocken Collections.
\end{abstract}

\title{
Keywords:
}

Māori language - grammar

Written Māori

Māori language - dialect

Manuscripts

Word count: 16,406 


\section{Part A: Bibliographic Plan}

\subsection{Introduction}

The Hocken Collections is the name given to a library now housed at the corner of Anzac Avenue and Parry Street, Dunedin. The Hocken collects extensively in the area of history and ethnography of New Zealand, the Pacific and Antarctica with special attention to Otago and Southland. The library owes its existence to Dr Thomas Morland Hocken offering his library to Dunedin and the people of New Zealand in 1897. The library was originally held in a special wing of the Otago Museum, and later moved on to the main campus of the University of Otago, and more recently to its present site. The library is managed by the University of Otago in trust for the people of New Zealand.

The Hocken Collections, and in particular the Hocken Manuscript and Archives Collection, have a large number of items, both published and unpublished, either written in te reo or relating to it. Many of these items would hold considerable interest for students of te reo, but are inadequately described in catalogues, making efficient access very difficult. Other items contain valuable historical or ethnographic information not readily available elsewhere. Although long suspected by some of the library staff, this situation has become more obvious following a recent project to improve descriptions of materials in te reo held at Hocken Archives. The Hocken Collections hold some old and rare grammars and word lists, and also have material in te reo scattered amongst bound volumes labelled Variae and Flotsam and Jetsam. These are bound 
volumes of individual sheets held in the Hocken Collections and contain all sorts of material, with often wide ranges of material within each volume.

Access to the published grammars and wordlists is facilitated through the University of Otago Library catalogue, but identifying the unpublished material written in, or concerning, te reo is more difficult. Manuscripts and archives are listed in a database, called Hākena, but being an archival database it does not often provide the sort of information people looking for te reo material might be seeking. The Variae and Flotsam and Jetsam volumes are not indexed in any way, so readers have no way of knowing that there is te reo material in them.

\subsection{Te reo in New Zealand libraries}

\subsection{Aotearoa/New Zealand}

Although there have been a number of articles written about Māori services in our libraries, few have addressed the issue of materials in te reo in our libraries. Those that have mentioned te reo have focused on service issues relating to te reo. None has addressed the unique value of te reo material held in our libraries and archives to learners of te reo, and the revitalisation of the language. Access to good quality reading material in Māori is essential for the further development of language in medium to advanced level learners.

There has been a regular stream of literature since the early 1990's, exploring issues around Māori services in libraries. Parekowhai \& Black (1990), Szekely \& Walker (2001), Pierce (2003), Campbell (2004) and Fletcher (2004) all discuss making services at their libraries more 
relevant to the needs of Māori. The 1994 publication Ka Mahi Tonu (Garraway \& Szekely, 1994) looked at bicultural services in New Zealand libraries. Beginning with a proposal for bicultural development by Dick Grace, it included a record of bicultural activities from 1992 1994, and a time-line of significant bicultural achievements from the same period.

The most comprehensive work exploring Māori library and information needs was the series that began with a commission from NZLIA ${ }^{1}$ for a research report into biculturalism. What became the Te Ara Tika project began with a research report by Tui MacDonald (1993) which provided a comprehensive literature review, and gave the results of a survey of public librarians. This initial report was followed by a series of hui around the country to gauge Māori attitudes to, and aspirations for, library and information services. The resultant report (Szekely 1997) highlighted many suggestions for improvement. In reference to Māori resources and te reo resources Szekely noted that "Māori language resources were mentioned specifically in relation to the needs of kōhanga reo, kura kaupapa, schools and tertiary studies". He further notes "It was widely acknowledged that there is a general lack of Māori language material available in published print form" (p51). Language issues also arose in other connections, such as the need for Māori speaking staff, the need to make manuscripts in Māori more readily available, as well as naming in Māori and bi-lingual signage.

It is these findings concerning the need for access to more te reo material, including manuscripts, that has prompted this bibliography.

\footnotetext{
${ }^{1}$ The Library and Information Association of New Zealand, fore-runner to LIANZA, the Library and Information Association of New Zealand Aotearoa.
} 


\subsection{Some Indigenous comparisons}

In many parts of the world, commentators are writing on issues to do with Indigenous knowledge, libraries and archives and other information centres. One of the most active areas of such inquiry is within the Aboriginal and Torres Strait Islander population of Australia, and one of the most prolific writers is Dr Martin Nakata. Nakata is Professor and Director of the Indigenous Academic Development Unit at Jumbunna Indigenous House of Learning at the University of Technology, Sydney. Nakata has written and co-written over 60 articles on Indigenous library and information issues, one of which "discusses Indigenous knowledge and its intersection with the LIS sector in Australia, drawing attention to its significance and relevance to Indigenous Australians". (Nakata et al, 2005, p9). Jacob Pilot (2005) discusses initiatives developed by the State Library of Queensland in regard to services for Queensland Aboriginal Peoples.

The language situation is very different for the Indigenous peoples of Australia, firstly because their languages are so diverse and there are such large numbers of them. Secondly, they have suffered much greater language loss than have Māori. To find comparative discussion on Indigenous language issues and libraries requires going further afield.

Ahgeak and Ongley (1999) discuss library services to Inupiat Eskimos. The Inupiat reside in the North Slope Borough, the most northerly municipality in the United States. All the Inupiat villages are inside the Arctic Circle and none is accessible by road (p.24). Ahgeak and Ongley discuss the establishment of an Inupiat cultural centre, which provides a working space and tools for traditional crafts, a space for teaching, lectures and large gatherings, an Exhibit Hall and a library. The library "is seen as an integral component of ... efforts to perpetuate and preserve 
the language and culture of the Inupiat people." (p.25). The library is also the public library for the borough and the academic library for the college. As was the case with te reo until very recently, the language is not being transmitted inter-generationally, and its survival status is critical. A Heritage Centre has been established to transmit language and tradition to the young by way of story telling, drawing on the manuscript collections of stories that have been collected and recorded since the 1960's. The Library has embarked on a number of initiatives, including expanding its archive collections, and employing an archivist who is an expert in Inupiat literature and language.

Peter Sarri (1999) writes of libraries in Sapmi, the Sami name for their traditional lands in northernmost Norway, Finland and Sweden and the Kola Peninsula. The Sami language has suffered rigorous repression in the past, but in recent years new language laws have come into force and schools are becoming more active in promoting the Sami dialects (p31). Initiatives in Sweden include the appointment of a Sami library counselor. There is a Sami public library book deposit, which holds 3,000 books in the Sami language. Other libraries also hold stocks of Sami literature. In Norway, a special Sami library was set up in the 1950's and there are a number of other libraries in Norway with significant Sami collections. There is a special Sami library in Rovaniemi, Finland. A lot of effort is put into ensuring that public libraries in the Sami district of Lapland are permanently stocked with books in the Sami language, and so forth. The example of the Sami people is an inspiring one, as their territory crosses the borders of so many colonial nations.

Leanne Hinton (2001) has described the use of archives in the revitalization of native Californian languages. A workshop is held on a regular basis at the University of California, Berkeley, for 
"people whose ancestral languages have no speakers at all" (p419). They meet with linguists "to learn how to find linguistic materials and make use of them for language learning purposes" ( $p$ 419). Participants are introduced to the types of resources held at the University - publications, dissertations, field notes and sound recordings - and how they can use them to help reconstruct their languages.

\subsection{Existing bibliographies}

There are a number of bibliographies and inventories that deal with various aspects of Māori material. An annotated list of a selection of these follows. There are those that deal with published Māori material of a general nature (items 1 -4) and others that deal with published material in te reo, or relating to language learning (items 5 -12). Items 13 - 16 deal with unpublished materials in particular collections or repositories and items 17 - 19 with a particular tribal area.

1. A bibliography of publications on the New Zealand Māori and the Moriori of the Chatham Islands, compiled by C. R. H. Taylor, 1972. This volume is an update of the New Zealand and Māori section of Taylor's Pacific bibliography.

2. Recent Māori publications, compiled by Sally Weatherall, 1994. This is a list of books relating to things Māori published since 1993.

3. Whaia te Matauranga: a guide to Maori resources, compiled by Gwenda Pearson, 1993. This is a guide to Māori related publications held in the Ministry of Education Library.

4. Whaia te Matauranga II: a guide to Maori education resources, compiled by the Ministry of Education Library, 1995. This is a guide to publications relating to Māori education held in the Ministry of Education Library. 
5. A bibliography of printed Māori to 1900, and Supplement, compiled by Herbert W. Williams, 1975. Annotates all printed material in te reo up to 1900.

6. Books in Māori, 1815-1900: an annotated bibliography, compiled by Phil Parkinson \& Penny Griffith, 2004. An update of Williams' bibliography, with additions.

7. Annotated bibliography of Māori bilingual resources published since 1980 for children, compiled by Lena Crawford, 2001. This bibliography was compiled as an MLIS ${ }^{2}$ project, and contains material aimed at children who are second language learners of te reo.

8. A bibliography of Māori language resources for primary, intermediate and secondary schools 1990-2000, held at the National Library of New Zealand, compiled by Gabrielle Hikaka, 2000. This bibliography, as the title suggests, is restricted to material held at the National Library, and includes a range of language resources.

9. He pukapuka i roto i te reo Mãori, compiled by Chris Szekely, 1990. This is an annotated list of te reo resources held at the Auckland office of the National Library.

10. Maori language bibliography, 1969-1979, compiled by Peter Ranby, 1980. This lists published works in te reo between 1969 and 1979.

11. Materials for teaching and learning the Maori language: a bibliography of published materials for teaching Mãori to speakers of other languages, compiled by Richard Benton, 1979.

12. He rauemi awhina: index of Maori language learning materials, 1991-96, compiled by Huriana Raven, 1997.

13. A Tribal Guide to Manuscript Material Relating to Maori History and Culture, compiled by Jeffrey Sissons in 1980-1, describes 180 items in 48 collections held at the Auckland

\footnotetext{
${ }^{2}$ Master of Library and Information Studies
} 
Institute and Museum. The guide was arranged alphabetically, in $58 \mathrm{iwi} /$ hapū sections (Curnow, 1995, Intro.).

14. Nga Pou Arahi: ko te rarangi-a-iwi o nga tuhituhinga mo nga taonga Maori, ara mo te reo, mo nga whakapapa, mo nga waiata, mo nga korero, mo nga tikanga, mo nga whakatauki, compiled by Jenifer Curnow, 1995. This inventory describes 298 collections in the Auckland Institute and Museum, and is an extension of Sissons' guide. Collections are arranged according to 15 tribal areas. Where manuscripts relate to more than one tribal area they are listed under all headings, rather than referring from one section to another. Individual entries show the manuscript title, dates covered, description, the language it is written in and details of what the manuscript is about. Also included are details about the writer and any relevant cross-references, plus the access details.

15. Annotated bibliography of Maori language sources in the Alexander Turnbull library with regard to the claim in the Te Tau Ihu o Te Waka-a-Mäui Region, compiled by Steven Chrisp, 1999, for the Waitangi Tribunal. This bibliography is very specific, both as to where the sources are held (ATL) and subject matter.

16. Hand-list of certain books and papers containing information relating more or less directly to the Māori of New Zealand, and Hand-list of certain papers relating more or less directly to the Mãori race, and published in various publications, compiled by Augustus Hamilton with the Dominion Museum, 1900[?]. Both these lists cover much of the same material. The second is a reprint of an article in Transactions of the New Zealand Institute, 1900[?].

17. Nga taonga o te Tai Tokerau: he pukapuka kahui korero, compiled by Jenifer Curnow, Hinerangi Himiona and Liesl Williams, 1998. This bibliography includes manuscripts, theses and books about Te Tai Tokerau, found in major libraries of New Zealand. 
18. Māori people and the library: a bibliography of Ngāti Kahungunu and Te Waka o Takitimu resources, compiled by Kathie Irwin and Willis Katene, 1993. As the title states, this is a restrictive bibliography of resources from a specific tribal area.

19. Sources for Rangitane history in the Port Nicholson Deed District: sources held in the Alexander Turnbull Library: a report, compiled by Steven Chrisp, 1998. This is an annotated bibliography of primary sources, in both Māori and English, held in the Alexander Turnbull Library, relating to the history of Māori in the Port Nicholson Deed district.

I have not been able to identify any bibliography that specifically covers te reo manuscripts as regards their value as language materials, nor is there a bibliography of Māori material in the Hocken Collections. With the possible exception of items 17 and 18 above, which I have been unable to inspect first-hand, none of these bibliographies covers any of the unpublished material held at the Hocken Collections. These two items, being iwi specific, do not in any way duplicate the content of this bibliography. Some of the bibliographies listed include published material held at the Hocken Collections, for reasons explained below (see 3.1).

\subsection{Objectives, audience and impact}

Publishing houses such as Learning Media and Huia Publishers publish a considerable volume of te reo material. However, much of this is aimed at child learners or those with a low level of language competence. Material is also being published for kura kaupapa and whare kura pupils, but these publications tend to concentrate on the learning curriculum. The amount of published material available for those wishing to expand their language competence by exposure to variety in genre and dialect is very limited. 


\subsection{Objectives}

This bibliography presents unpublished resources in te reo or concerning te reo held at the Hocken Collections, in one annotated bibliographic list that includes information on the linguistic features of the material, where appropriate. Published material is not included because, as earlier observed (see Introduction) these items are more easily accessed as they are listed on the University of Otago Online catalogue and also on the National Bibliographic Database.

\subsection{Output format}

The bibliography is available in print and exists also in raw form as an EndNote library. It will be made accessible as a PDF file on the Hocken Collections website. At some future point, it is hoped to be able to present the contents as an online database that can be regularly added to as further, related projects are undertaken.

\subsection{Audience and impact}

The project will be of immediate and direct benefit to the students of Te Tumu, School of Māori, Pacific and Indigenous Studies at the University of Otago, and has the support of the School. It will also, of course, have much more wide reaching value for students of, and researchers into, early written Māori.

\subsection{Bibliographic scope}

The Hocken Collections, a branch of the University of Otago Library, includes a Manuscript and Archives Collection, a Print Collection, and a Pictorial Collection as well as maps, music, 
ephemera, posters and photographs. The scope of this bibliography is to gather and describe te reo material in the Manuscripts and Archives Collection. There are a number of volumes of miscellaneous, loose-leafed unpublished material, bound together as Variae and Flotsam and Jetsam that were a part of Dr Hocken's original bequest. Although partially listed on the Archives and Manuscripts database, Hākena, these volumes are housed with the Print collection. There are a few items in Māori in these volumes but they are not included in this bibliography, because of the exigencies of resources available, including time, associated with the current project.

Items in the Hocken Manuscript and Archives Collection are arranged according to Collection. Collections are groupings of material with the same provenance and usually lodged together. Individual items within collections are usually arranged in accordance with the collector's arrangement. Collection titles are assigned according to the name of the collector and usually some indication of the format, for example: Gilfedder family: Papers. The collector's titles are generally used for individual items, if assigned, however these may be modified to avoid duplication of titles. Where there is only one item in the collection, the collection title and item title will be the same.

\subsection{Subject coverage and limitations}

Only material in te reo, or items that describe aspects of te reo, are included, as the intent is to provide a resource for those pursuing a study of te reo, either as second language learners or as linguists. Literary compositions in te reo, such as waiata, haka, and whakatauki are included, as examples of te reo in use, as are whakapapa charts. As mentioned above, only material in 
archives collections are included, with the Flotsam and Jetsam and Variae volumes excluded (refer 4.0 above)

\subsection{Location}

All material included is from the Hocken Collections, and held in the original at Hocken. Again, the inclusion of copies of material held in original elsewhere was considered, but rejected for the current project because of restraints on resources.

\subsection{Timeframes}

There has been no discrimination applied in terms of time frames of the material covered, however, the nature of the Hocken Collections means that most material is from the second half of the $19^{\text {th }}$ Century, with a little from the early $20^{\text {th }}$.

\subsection{Bibliographic focus}

The focus of this bibliography is on the linguistic value of te reo materials held at the Hocken Collections. The primary aim is to annotate the type of language, the genre, and the dialect where it can be ascertained. Any information available on the language skills of the writer is also included. Manuscripts with te reo content that amounts to more than simple headings in Māori are included. Waiata are also included because of the richness of language they exhibit. Place names are also included where their origins are explained. Whakapapa has not been particularly sought, but is included where it occurs in conjunction with other material. The language of whakapapa is very stylised and varies little from whakapapa to whakapapa. Whakapapa material should be inventoried separately, preferably by someone with expert knowledge of whānau connections. 


\subsection{Presentation}

\subsection{Arrangement of entries}

Two forms of arrangement were considered and rejected in favour of arranging by collection. A collection is a group of items arranged together because of shared provenance. Collection titles usually reflect the provenance of the collection as well as briefly describing the format of material. The initial intent was to arrange by time spans: before a set orthography was established (pre-1863), the period from 1863 to the turn of the century, and early $20^{\text {th }}$ century. This arrangement would have been helpful for the student of historical syntax, but was rejected as there was not the range of times represented in the Hocken Collections that I thought there may have been. In fact, the material collected for inclusion was very heavily weighted towards an 1860-1880 timeframe, which would have made the arrangement very top-heavy.

My second thought was to arrange by dialect or geographical area, using broad dialect divisions to effect this arrangement. These broad divisions would have been based on Bruce Biggs' dialect areas: Southern, Eastern and Western (Biggs, 1989). However, on closer analysis of the items it was obvious that a more detailed $i w i$ division was necessary to fully reflect the origins of the language used in these pieces.

The items are, therefore, arranged according to a short Collection Title (for example: the Shortland Collection, being items collected by Edward Shortland; the Beattie Collection, being items collected by James Herries Beattie) and a further division, labeled 'Miscellaneous' for single items and collections of only one or two items. Each division begins with a short description of the Collection and the person who gathered the items together (the Collector). 


\subsection{Format of entries}

Entries are formatted using an adapted version of the EndNote Manuscript reference style, and the 'Show all' export style, as seen below.

\section{Collector:}

Year:

Title:

Collection Title:

Reference Number:

Iwi/hapū:

Keywords:

Abstract:

Notes:

Collector is the person who gathered the items together. Title is usually the name given to an item by the collector, however, it may be changed by the archivist to prevent duplication of titles or to better represent the content. Collection Title is the title given to the group of items assembled by one collector. It usually comprises the collectors name and an indication of the format of the items, for example: Gilfedder family: Papers. Reference number is essentially the call number. It is the number by which archives staff identify the item for retrieval.

Iwi/hapū headings are taken from the 'Iwi/hapū names list', September 2004

(http://iwihapu.natlib.govt.nz/iwi-hapu/index.htm), with the addition of two purpose-made headings: 'general', used when it is not possible to attribute the material to any particular $i w i$ or dialect; and 'pākehā' to denote Māori written by English-speaking second-language learners of Māori. This heading is used also to attribute subject matter to a particular $i w i$, where it is not 
possible to identify a particular dialectal influence. Those headings relating to dialect are marked with an *, for example:

\title{
Iwi/hapū:
}

Waikato*

Ngāti Tūwharetoa

\begin{abstract}
Denotes that the item includes material written by a Waikato writer, but also contains material pertaining to Ngāti Tūwharetoa.
\end{abstract}

Keywords headings include the following Library of Congress Subject Headings relating to te reo content: Māori language - Glossaries, vocabularies, etc; Māori language - Grammar and Māori language - Pronunciation. Corresponding Māori terms used are: papakupu, wetereo, and whakahua. Only the term wetereo is taken from 'Ngā Ūpoko Tukutuku/Māori Subject Headings', June 2006 (http://mshupoko.natlib.govt.nz/mshupoko/), as other aspects of te reo are not yet covered in the headings list. I have also raised headings to reflect the style of language included in the item. These headings are: karakia (ritual chant/prayer), waiata (song), haka (posture dance), whakataukī (proverb), whaikōrero (speechmaking), karanga (ritual calling), whakapapa (genealogy), letters, narrative, place names and legal documents.

The Abstract is the annotation. Annotations are both informative and evaluative in nature. The informative element comprises information on the subject matter and general content of items. This content description is in many cases an abbreviated form of the Scope and Contents notes from the Hākena database. The evaluative aspect is the linguistic analysis of the items, noting dialect, language skill of the writer and type of writing, where this can be ascertained. 
The Notes field only appears where there is an access restriction in place for the manuscript, or a see also reference.

\subsection{Indexing}

The indexes include keywords used, iwi/hapū headings and names of authors/contributors.

\subsection{Future development of the bibliography}

This bibliography is regarded very much as a work in progress. I see it as a basis for a more comprehensive work covering all material in te reo or relating to it in the Hocken Collections, including te reo material to be found in the Flotsam and Jetsam and Variae volumes, manuscript items held in copy at Hocken and in original elsewhere, and selected published material such as early vocabularies and grammars.

To facilitate this further development it would be beneficial to convert the bibliography to an online database that can be built up incrementally. 


\subsection{Bibliography to Part A}

Ahgeak, K. I., \& Ongley, D. (1999). Library Services to the Inupiat Eskimos of the North Slope of Alaska. In C. Szekely (Ed.), Issues and Initiatives in Indigenous Librarianship (pp. 24-30). Auckland: Te Rōpū Whakahau.

Biggs, B. (1989). Towards the Study of Maori Dialects. In R. Harlow \& R. Hooper (Eds.), VICAl 1: Oceanic Languages: Fifth International Conference on Austronesian Linguistics, Part 1 (pp. 61-75). Auckland: Linguistic Society of New Zealand.

Campbell, J. (2004). Manaakitanga at Wellington City Libraries. Library Life(290), 20.

Curnow, J. (1995). Nga pou arahi: ko te rarangi-a-iwi o nga tuhituhinga mo nga taonga Maori, ara mo te reo, mo nga whakapapa, mo nga waiata, mo nga korero, mo nga tikanga, mo nga whakatauki. Auckland: Auckland Institute and Museum.

Fletcher, K. (2004). Resourcing Maori. Library Life(287), 27.

Garraway, J., \& Szekely, C. (1994). Ka mahi tonu: biculturalism in New Zealand librarianship 1992-1994. Wellington: The N Strategy Bicultural Action Group.

Hinton, L. (2001). The use of linguistic archives in language revitalisation: The native California language restoration workshop. In L. Hinton \& K. Hale (Eds.), The Green Book of Language Revitalisation in Practice (pp. 419 - 423). San Diego: Academic Press.

MacDonald, T. (1993). Te Ara Tika: Maori and libraries: a research report. Wellington: New Zealand Library and Information Association.

Nakata, M., Byrne, A., Nakata, V., \& Gardiner, G. (2005). Indigenous Knowledge, the Library and Information Service Sector, and Protocols. Australian Academic and Research Libraries, 36(2), 9 - 24.

Parekowhai, C., \& Black, R. (1990). Bus Stop, Wet Day, She's There, I Say. Archifacts, 29 - 35.

Pierce, H. (2003). Christchurch City Libraries seeks Maori views at Hui. Library Life(280), 10.

Pilot, J. (2005). Developing Indigenous Knowledge Centres. Australian Academic and Research Libraries, 36(2), 39 - 45.

Sarri, P. (1999). Girjeradjusat Samis - Libraries in Sapmi. In C. Szekely (Ed.), Issues and Initiatives in Indigenous Librarianship (pp. 31-35). Auckland: Te Rōpū Whakahau.

Szekely, C. (1990). He pukapuka i roto i te reo Māori. Auckland: Regional Services, National Library of New Zealand. 
Szekely, C. (1997). Te Ara Tika: Guiding Voices. Wellington: New Zealand Library and Information Association.

Szekely, C., \& Walker, J. (2001). More Maori using Manukau Libraries more often. Library Life(259), 22 - 23. 


\section{Part B: The Bibliography}

\section{Section 1: The Shortland Collection}

Dr. Edward Shortland (1812-1893) arrived in New Zealand in 1841 and was involved in various areas of colonial administration, including land claims. After returning to England for a period, he came back to New Zealand in 1880, and published Maori Religion and Mythology in 1882. Shortland was regarded as the leading European authority on Te Arawa tradition, and much of his collection is from that area. However, he also collected extensively elsewhere in the country. The following annotations concentrate on the Māori language aspects of the listed manuscripts. Further details on the contents of English language sections are available on the Hākena database.

1

Collector: Shortland, Edward Year: 18--

Title: Maori manuscript No. 1, mythology \& traditions

Collection Title: Shortland, Edward: Papers (ARC0020)

Reference Number: MS-0001 (PC-0001)

Iwi/hapū:

Te Arawa*

Ngāti Toa Rangitira

General*

Keywords:

Karakia

Whakataukī

Whakapapa

Narrative

Abstract: Māori language notes for Shortland's volume Māori Religion and Mythology, originally published 1882. Much of the material is from Te Arawa, showing features of Te Arawa dialect. Also contains whakapapa of Tamihana Te Rauparaha, and other material which is not identifiable as from any particular $i w i / h a p \bar{u}$. Includes karakia, whakatauki and whakapapa 
to illustrate narratives. Narrative topics include: creation, naming of various landmarks in Waikato and Rotorua Lakes regions, Te Arawa waka, the death of Whiro, and the story of Tinirau and Kae. Contributors include: Te Ngarara, Piripi Matewha, Ringori Te Ao (Te Arawa), Tamihana Te Rauparaha (Ngāti Toa).

Notes: Preservation copy issued in place of original.

2

Collector: Shortland, Edward

Year: 18--

Title: Maori manuscript No. 2, tradition - superstition

Collection Title: Shortland, Edward: Papers (ARC-0020)

Reference Number: MS-0002 (PC-0002)

Iwi/hapū:

Te Arawa*

Ngāti Hauā*

Ngāti Maru (?)

Keywords:

Waiata

Whakapapa

Karakia

Narrative

Abstract: Entirely in Māori, this item contains Te Arawa traditions concerning adventurers such as Ngatoro-i-rangi, Kahu, Ihenga and others and their travels. Narratives include explanations of place names in Northland area. Also contains traditions concerning Tainui Waka, tikanga concerning the construction of waka, and narratives about patupaiarehe (fairy folk).

Contributors include Ringori Te Ao (Te Arawa), Wiremu Tamihana Tarapipipi Te Waharoa (Ngāti Hauā) and Hauauru Taipari (Ngāti Maru?).

Notes: Preservation copy issued in place of original.

3

Collector: Shortland, Edward

Year: 18--

Title: Maori manuscript No.3', miscellaneous notes on Maori history and customs

Collection Title: Shortland, Edward: papers (ARC0020)

Reference Number: MS-0003 (PC-0003)

Iwi/hapū:

Ngāti Toa Rangatira*

General*

Keywords:

Karakia 


\section{Waiata \\ Whakapapa \\ Narrative}

Abstract: This item includes extensive notes, in Māori, on various rituals, including verbatim karakia and other chants associated with activities such as felling trees, canoe building, and food preparation. There are also waiata, whakapapa. Also includes narrative on the war between Te Rauparaha and Kāi Tahu at Kaiapohia (Kaiapoi), contributed by Wiremu Tamihana (Te Rauparaha).

Notes: Preservation copy issued in place of original.

4

Collector: Shortland, Edward

Year: 18--

Title: Maori manuscript No. 4, waiata - whakataukī, etc, miscellaneous

Collection Title: Shortland, Edward: Papers (ARC 0020)

Reference Number: MS-0004 (PC-0004)

Iwi/hapū:

Ngāti Paoa

Rongo-whakaata*

Ngāti Awa*

Ngāti Toa Rangatira*

Te Arawa*

Keywords:

Waiata

Haka

Whakataukī

Letters

Abstract: This item contains many waiata, translated and annotated by Shortland. Composers include Te Kooti Arikirangi (Rongo-whakaata), and subjects include Tuwhatu, Te Kahawai, Te Wharekohe (Ngāti Paoa). There are also tau, haka, ngeri and ruriruri, composed around the time of the battle of Rangiriri, with content about the Kingitanga. There is also an extensive section of whakatauki, translated and annotated by Shortland. Some attributed (to Ngāti Awa and to Te Rauparaha) but most are not. There are also miscellaneous letters in Māori, including from Ringori Te Ao (Te Arawa), and Wiremu Tamihana Tarapipipi (Ngāti Hauā).

Notes: Preservation copy issued in place of original.

\section{5}

Collector: Shortland, Edward

Year: pre-1883

Title: Manuscript entitled 'Hints on the study of the Maori language, its origin, structure and idiom: How to learn Maori; A short treatise on the origin, structure, idiom of the language'.

Collection Title: Shortland, Edward: Papers (ARC-0020) 
Reference Number: MS-0005 (PC-0005)

Iwi/hapū:

General*

Keywords:

Maori language - glossaries, vocabulary, etc

Maori language - grammar

Māori language - pronunciation

Wetereo

Papakupu

Whakahua

Abstract: This manuscript formed the basis of an informal textbook published by Upton \& Co in 1883. It includes an extensive explanation of speech particles, syntax and other grammatical features. There is also a discussion on the origin of the Māori language and comparisons to other languages. There is no identifiable dialect represented, it being a general grammar. Major headings covered are: Languages - their classification and analysis; Māori language - its characteristics; pronunciation; particles of speech; syntax; prepositions; verbs; tense; use of maku, naku, mana, nana; imperative forms; infinitive forms; the participle; the passive participle; subjunctive mood; conditional sentences; negative forms; interrogatives; temporal sentences; adverbs.

Notes: Preservation copy issued in place of original.

6

Collector: Shortland, Edward

Year: 1888

Title: Manuscript entitled 'Melanesian languages'

Collection Title: Shortland, Edward: Papers (ARC 0020)

Reference Number: MS-0006 (PC-0006)

Iwi/hapū:

General*

Keywords:

Māori language - pronunciation

Māori language - grammar

Wetereo

Whakahua 
Collector: Shortland, Edward

Year: 18--

Title: Melanesian dictionary

Collection Title: Shortland, Edward: Papers (ARC-0020)

Reference Number: MS-0007 (PC-0007)

Iwi/hapū:

Keywords:

Te Arawa*

Letters

Abstract: This item, as the title suggests, is a Melanesian dictionary. However, there are a number of loose leaf inserts, one of which is a letter in Māori from Te Arawa chief Ringori Te Ao to Governor Grey. The letter is a welcome to Grey with some advice to the returning Governor on the state of play from Te Ao's viewpoint.

Notes: Preservation copy issued in place of original.

8

Collector: Shortland, Edward

Year: 1863

Title: Outward letter book, Maori

Collection Title: Shortland, Edward: papers (ARC-0020)

Reference Number: MS-0013 (PC-0013)

Iwi/hapū:

Pākehā*

Keywords:

Letters

Abstract: This item contains letters written by various government officials to Māori. Most are in Māori, written by Englishmen who learnt Māori as a second language. Many of the letters are from Shortland himself, others are by Sir George Grey and Sir William Fox. A common theme of the letters is extolling the virtues of being loyal to the Government and avoiding association with the Waikato, claiming the Government are pacifist and Waikato the aggressors.

Notes: Preservation copy issued in place of original.

9

Collector: Shortland, Edward

Year: 18--

Title: Manuscript containing Maori notes on traditions, karakia and religion

Collection Title: Shortland, Edward: papers (ARC-0020)

Reference Number: MS-0014 (PC-0014)

Iwi/hapū:

Ngāti Whātua 


\begin{abstract}
Ngāti Tamatera
General*

Keywords:

Karakia

Whakapapa

Narrative

Abstract: This item contains both English and Māori language material. There is a considerable collection of karakia, tau, poipoi and other ritual chants to do with childbirth, death, mental illness and dealing with makutu. There is also a whakapapa from Ngāti Tama-te-ra and one for Ngaro-ki-te-uru of Tāmaki (Auckland). There is also a letter, in Māori, containing the text of an 1861 address by 'the chiefs of New Zealand'. The item also contains four loose leaves from Te Amoneke, concerning the history of Tütanekai and Hinemoa.
\end{abstract}

Notes: Preservation copy issued in place of original.

10

Collector: Shortland, Edward

Year: 1880

Title: Manuscript containing Maori notes on mainly genealogies, karakia and customs

Collection Title: Shortland, Edward: papers (ARC-0020)

Reference Number: MS-0015 (PC-0015)

Iwi/hapū:

$$
\begin{aligned}
& \text { General* } \\
& \text { Kāi Tahu* } \\
& \text { Te Arawa* } \\
& \text { Ngāti Toa Rangatira* } \\
& \text { Ngāti Raukawa (?) } \\
& \text { Ngāti Kahungunu (?) } \\
& \text { Ngāti Te Upokoiri (?) }
\end{aligned}
$$

Keywords:

Māori language - glossaries, vocabularies, etc

Papakupu

Whakapapa

Waiata

Karakia

Whakataukī

Narrative

Abstract: This item contains material in Māori and English. Contains many whakapapa, including some starting with Te Po, and others detailing the unions of Rangipōtiki and Papatūānuku, and Tāne-nui-a-rangi and Hine-ahu-one. Whakapapa charts include, among others, Te Wirihana, Te Rauparaha (Ngāti Toa), Te Mangu, Wakairikawa, Parewahaika and Te Whata (Te Whatanui of Ngāti Raukawa?), Uenuku. The item also contains a number of karakia, pure and other chants associated with activities such as: removing tapu, blessing weapons, kumara planting, identifying thieves, broken teeth and other injuries, building a waka, restoring 
people taken into slavery to their tribe, preserving heads. Also contains narratives, in Māori, including two recounting dreams, and a background narrative, mostly in Māori, about the circumstances of the composition of a waiata composed by Whatitata (Kāi Tahu) at Kaikoura. Other narratives include stories about Parekawa and Peketahi, Waipuhero and Hotumauea, Tahae, the realm of Te Reinga, and the patupaiarehe. There is also a glossary of words relating to childbirth, and karakia relating to childbirth and the newborn, as well as a glossary of kinship terms, and divisions of time. Contributors include: Renata Tangata (Renata Kawepo of Ngāti Te Upokoiri and Ngāti Kahungunu?), Petera Te Pukuatua (Te Arawa), Piripi Matewhau

Notes: Preservation copy issued in place of original.

11

Collector: Shortland, Edward

Year: 1863-64

Title: Inward letter book, Maori

Collection Title: Shortland, Edward: papers (ARC-0020).

Reference Number: MS-0016 (PC-0016)

Iwi/hapū:

Ngāti Toa Rangatira*

Ngāti Hauā*

Ngāti Whakaue*

Waikato*

Ngāti Whātua*

Keywords:

Ngāti Maniapoto*

Letters

Whaikōrero

Abstract: This item contains copies of inward correspondence to Edward Shortland, Sir George Grey and Sir William Fox. Contributors include: Tamihana Te Rauparaha (Ngāti Toa

Rangatira), Pekamu Winiata (also known as Tohi Te Ururangi - Ngāti Whakaue), Wiremu Hoete, Tamati Ngapora (Waikato), Patara Te Tuhi (Waikato), Wiremu Tamihana Tarapipipi Te

Waharoa (Ngāti Hauā). There is also a report of a hui in Te Kuiti, with transcripts of speeches, in Māori, including by Paora Tuhaere (Ngāti Whātua) and Rewi (Maniapoto).

Notes: Preservation copy issued in place of original.

12

Collector: Shortland, Edward

Year: 18--

Title: Notebook containing Māori vocabulary

Collection Title: Shortland, Edward: papers (ARC-0020)

Reference Number: MS-0018 (PC-0018)

Iwi/hapū: 
Keywords:

General*

Māori language - glossaries, vocabularies, etc

Papakupu

Abstract: This item is an extensive Māori vocabulary list. The list is arranged alphabetically, with some entries having reference to sample sentences in Grey's Mythology. This is a fair copy of rough notes contained in MS-0017.

Notes: Preservation copy issued in place of original.

13

Collector: Shortland, Edward

Year: 18--

Title: Notebook containing Maori vocabulary and botanical notes

Collection Title: Shortland, Edward: papers (ARC-0020)

Reference Number: MS-0017 (PC-0017)

Iwi/hapū: General*

Keywords:

Māori language - glossaries, vocabularies, etc

Papakupu

Abstract: This item is a rough copy of the vocabulary list reproduced in MS-0018. Item also contains botanical notes in English.

Notes: Preservation copy issued in place of original.

14

Collector: Shortland, Edward

Year: 18--

Title: Notebook containing Māori language notes

Collection Title: Shortland, Edward: papers (ARC-0020)

Reference Number: MS-0019 (PC-0019)

Iwi/hapū:

General*

Keywords:

Māori language - glossaries, vocabularies, etc

Papakupu

Karakia

Abstract: This item contains both Maori and English language material. There is a ritual chant, a tuuaakaha mo te whawhai wahine which appears to be to provide strength to a woman for a fight. The main features of the item are a glossary of Māori terminology and sample sentences in the Māori language. The item is somewhat disordered.

Notes: Preservation copy issued in place of original. 
15

Collector: Shortland, Edward

Year: $1842-43$

Title: Notebook comprising Maketu journal and common-place book B, New Zealand

Collection Title: Shortland, Edward: papers (ARC-0020)

Reference Number: MS-0020 (PC-0020)

Iwi/hapū:

Keywords:

General*

Waiata

Narrative

Abstract: This item comprises two volumes. The first volume is predominantly in English, consisting mainly of a journal of Shortland's travels to Maketu, commencing 29 November 1842 . The last portion of the journal has notes in English and Māori about Te Mutu (Eparaima Te Mutu Kapa or Mutu Paratene Kapa - Aupouri and Waikato) and his people and the boundaries of Ngā Rata (Matakana), together with discussions of land claims, incidents of muru (plundering for retribution) and the Government attempts to end this practice. There are also notes on the difficulties of travel, and reference to the death of Wakefield and others killed by Te Rauparaha and Te Rangihaeata. The second volume is a journal commencing July 1843 relating to a visit to Te Rauparaha at Otaki. The volume ends with notes (upside down) on crimes by Pākehā against Māori and a waiata whaiaipo.

Notes: Preservation copy issued in place of original. Parts of the original manuscript are very faint, making reading difficult.

16

Collector: Shortland, Edward

Year: 18--

Title: Notebook comprising a journal of a journey to Matamata, Tauranga and Waikato and common-place book A, New Zealand

Collection Title: Shortland, Edward: papers (ARC-0020)

Reference Number: MS-0022 (PC-0022)

Iwi/hapū:

Ngāi Te Rangi

Ngāti Ranginui

Ngāti Tamatera

General*

Pākehā*

Keywords:

Karakia

Whakataukī

Waiata 
Haka

Narrative

Abstract: This item comprises two volumes: a journal and a notebook, which have been bound together in the preservation copy. The notebook, mostly in Māori, contains a number of karakia and other ritual chants, including for dragging and paddling a canoe, a niu (divination). There are also whakatauki, waiata, haka and descriptions of games. Although these are not attributed it is reasonable to assume, as they appear with the Journal of a trip to Maketu and Tauranga that they originate from Ngāi Te Rangi and/or Ngāti Ranginui. Also included is a commentary on Pākehā profiting from Māori land, and narratives, in Māori, about the taniwha Ureia [or Hureia] of Hauraki and Haumia of the Manukau, and the plundering of a potato crop, contributed by Te Awhe. There is also a narrative, in Māori, about an incident following the killing and cooking of a slave, which also refers to other events related to disputes between Ngāti Tama-te-ra and Ngāi Te Rangi of Tauranga, related by Te Tiwha. There are also odd pages in Māori in the Journal, probably written by Shortland himself.

Notes: Preservation copy issued in place of original.

17

Collector: Shortland, Edward

Year: 1843-44

Title: Journal, 1843-1844. Middle island of New Zealand

Collection Title: Shortland, Edward: papers (ARC-0020)

Reference Number: MS-0023 (PC-0023)

Iwi/hapū:

Kāi Tahu*

Keywords:

Māori language - glossaries, vocabularies, etc

Māori language - pronunciation

Māori language - grammar

Wetereo

Papakupu

Whakahua

Whakapapa

Narrative

Abstract: This item includes the record of a journey from Waihao (in English), a visit to Timaru, and a further journey from Akaroa. There is discussion on Māori place names on Banks Peninsula and records of interviews with Moki of Waituaitara and Te Ruahikihiki from Turaka. There are historical details of Māori settlement around Kaiapoi, and a list of settlements and people at Tapui-te-roa (Pigeon Bay). Perhaps of greatest interest are the 8 pages of Kāi Tahu word lists (which include examples of the use of ' 1 ') and linguistic notes on the Southern dialect. The narrative headed 'Tuhawaiki's tale' also contains sections in Māori

Notes: Preservation copy issued in place of original. 
18

Collector: Shortland, Edward

Year: 1856

Title: Volume containing notes on Maori vocabulary, syntax, waiata and whakataukī

Collection Title: Shortland, Edward: papers (ARC-0020)

Reference Number: MS-0025 (PC-0026)

Iwi/hapū:

Te Arawa*

Ngāti Hauā*

Ngā Puhi*

Waikato*

Ngāi Te Rangi *

Keywords:

Māori language - glossaries, vocabularies, etc

Māori language - grammar

Papakupu

Wetereo

Whakapapa

Waiata

Karakia

Haka

Whakataukī

Narrative

Abstract: This item is in Māori and English. There are waiata, a ngeri, a record of a dream, and poroporoaki to the dead, all with English translations and notes. There are glossaries of terms relating to plants, fish, fishing and eeling, and definitions and linguistic notes concerning haka and whakatauki. Narratives include stories about the return of a spouse who has deserted, and the journeys of Uenuku and Tiorea. Commentary on kawa ceremony, provided by Paora Tuhaere is also included as are whakapapa relating to Tainui and Ngāi Te Rangi and hapū of Ngāti Whanaunga and Te Kawerau. There are also ten pages (28-38) of dialectal variations of various vocabulary items for Te Arawa, Ngāti Hauā and Ngā Puhi.

Notes: Preservation copy issued in place of original.

19

Collector: Shortland, Edward

Year: 1862-64

Title: Journal

Collection Title: Shortland, Edward: papers (ARC-0020)

Reference Number: MS-0034 (PC-0034)

Iwi/hapū:

Ngāti Raukawa*

Ngāti Kahungunu* 


\title{
Ngāi Te Rangi \\ Waikato*
}

Keywords:

Māori language - glossaries, vocabularies, etc

Papakupu

Waiata

Whakataukī

Whaikōrero

\begin{abstract}
This item, mostly in English but containing some material in Māori, includes accounts of journeys. Destinations include Coromandel, to visit Ngāi Te Rangi, Waiharakeke to visit Wiremu Tamihana Tarapipipi (including Wiremu's explanations of the origins of the King Movement), Maketu, Otumoetai, Tangimoana, Waitakaruru, and Piako. There are also accounts of rünanga sittings, at some of which Shortland acts as judge. Māori language content is limited to: waiata; whakataukī (including one attributed to Ngāti Raukawa); a political message from Te Moananui (Ngāti Kahungunu); notes about Tapuae (a Waikato ancestor); and a glossary of lying positions.
\end{abstract}

Notes: Preservation copy issued in place of original.

\section{0}

Collector: Shortland, Edward

Year: 1842-45

Title: Outward letter book

Collection Title: Shortland, Edward: papers (ARC-0020)

Reference Number: MS-0086/001 (PC-0027)

Iwi/hapū:

Waikato*

Ngāti Mahuta*

Ngāi Te Rangi *

Kāi Tahu

Pākehā*

Keywords:

Letters

Whakapapa

Abstract: This letter book contains letters written by Shortland, concerning various issues relating to his role as Protector of Aborigines. Many detail land disputes or the complexities of land transactions between European settlers and Māori. There is also some information on the Māori of Banks Peninsula and the eastern coast of the South Island in general. Most of the material is in English, but some in Māori. Of the material written in Māori, some is written by Shortland, displaying the language of an Englishman who learnt Māori as a second language. There is, however, also some material written by Māori. Material written by Māori, in Māori, includes: a letter from Te Wherowhero (labeled 'Enclosure $C^{\prime}$ ), showing a list of Te Wherowhero's lands in Waikato which he is asking to have printed 'lest [they] be sold clandestinely'; a letter (with translation) to the Government from Waiapo, of Turua (dated July 
6th 1843) asking that a farmer named Abercrombie be required to remove his stock which is wandering on Waiapo's land on Great Barrier Island; a copy of an agreement between William Moore and local Māori of Maketu. Letters in Māori written by Shortland include: Shortland's response to Te Wherowhero discussing some disputed land that appears on Te Wherowhero's list; a letter from Shortland to Titipa of Matakana (dated March 16, 1843); a letter from Shortland to George Clarke (dated April 10th 1844) containing the copy of the William Moore agreement mentioned above; a letter from Shortland to Kitahi (dated June 14th 1844) discussing details of compensation payments. The item also contains a number of whakapapa, including one of Ngāi Te Rangi.

Notes: Preservation copy issued in place of original.

21

Collector: Shortland, Edward

Year: 1845-52

Title: Letter book

Collection Title: Shortland, Edward: papers (ARC-0020)

Reference Number: MS-0086/002 (PC- 0028)

Iwi/hapū:

Pākehā*

Te Arawa*

Ngāti Awa*

Mataatua*

Ngā Puhi*

Keywords:

Ngā Māhanga

Letters

Whakapapa

Narrative

Abstract: This letter book is comprised mostly of letters written by Shortland. Most are in English, but there a some in Māori, which display the characteristics of an English-speaking second language learner of Māori. Contents of the letters cover such things as disputes between European settlers and Māori, the need for regularising commercial transactions between the races, and inter-tribal disputes, particularly in the Bay of Plenty. Other Māori language material (in pages 60 -144) is in the form of whakapapa, including of Ngāti Awa, Te Arawa, Mataatua, and Ngā Puhi, as well as narratives concerning Te Aroha (by Wiremu Hopihana - William Hobson?), Te Arawa ancestors (by Paora Puruhi), Ngā Puhi ( by Hoani Timo) and the descendents of Māhanga (by Wiremu Kingi).

Notes: Shortland, Edward: papers (ARC-0020) 
Collector: Shortland, Edward

Year: 1850-55

Title: Volume containing notes on Maori language, customs and traditional history

Collection Title: Shortland, Edward: papers (ARC-0020)

Reference Number: MS-0096

Iwi/hapū:

General*

Ngāti Hauā*

Ngāti Toa Rangatira*

Waikato*

Te Aupouri*

Rarawa*

Te Arawa

Keywords:

Ngāti Maniapoto

Maori language - glossaries, vocabularies etc

Maori language - grammar

Papakupu

Wetereo

Letters

Narrative

Whakapapa

Karakia

Haka

Waiata

Abstract: The majority of this volume is in the Māori language, with English translation on opposing pages. The first 57 pages comprise a dictionary (wordlist) of Māori compiled by Shortland. The following 13 pages contain language notes, including how to ask and answer certain questions, kinship terms, terminology for body parts, the use of $a i$ and nei, a six page section of sample sentences, and a section on linear measure and the concepts of iho and ake. There are two letters from Wiremu Tamihana Tarapipipi Te Waharoa, one concerning the custom of ohaki and inheritance of land, the other about customs to do with birth and warfare. These are followed by notes by Shortland on the language use in the second letter. Also in the volume is a narrative by Tamihana Te Rauparaha about Te Rauparaha senior's battles with Kāi Tahu, which includes a ngeri and a waiata. Narratives include: an account by Shortland about the Bishop's injury at the hands of Poutama Paretekorae of Ngāti Maniapoto; an account of the origins of cannibalism (unattributed); a narrative of the Te Arawa canoe's voyage from Hawaiiki, which includes a whakapapa of descent lines to Te Pukuatua (unattributed); a story by Tamati Ngapora (Waikato) concerning the voyage of Tainui; an account of the discovery of New Zealand, the canoes and their landing points, including whakapapa of Te Aupouri and Rarawa, karakia relating to death at sea, kumara cultivation and fishing (taken from a letter by Mr. Puckey, a missionary of Kaitaia). Other narratives talk of Kupe's voyage and the Hokianga, and there is a karakia used by Ngatoro-i-rangi to save the Te Arawa canoe from capsize. There is 
also a seven page comparative table of English, Tahiti and the Society Islands, Hawaiian, Māori, Malay, Madagascan, Javanese, Sian, Anam and Tagala vocabulary.

\title{
23
}

Collector: Shortland, Edward

Year: 1863-64

Title: Correspondence and notes

Collection Title: Shortland, Edward: papers (ARC-0020)

Reference Number: MS-0385/001

Iwi/hapū:

$$
\begin{aligned}
& \text { Ngāti Hauā* } \\
& \text { Ngāti Tūwharetoa* } \\
& \text { Waikato* } \\
& \text { Ngāi Te Rangi } \\
& \text { Ngāti Ranginui }
\end{aligned}
$$

Keywords:

Letters

\begin{abstract}
This item comprises correspondence and notes relating mainly to the Waikato, Hauraki and Tauranga regions. Some letters are in Māori, but most are in English. Contributors include Hoani Papita Te Wharangi (Ngāti Tūwharetoa), Hou Te Wetuki and Wiremu Tamihana Te Waharoa (Ngāti Hauā), Edward Puckey and Sir William Fox. There is also a document which begins: "Ko nga kupu a tetehi pukapuka ki a Wi Tamihana na Waikato" ands shows clear attributes of Waikato dialect.
\end{abstract}

24

Collector: Shortland, Edward

Year: $1842-70$

Title: Correspondence and notes

Collection Title: Shortland, Edward: papers (ARC-0020)

Reference Number: MS-0385/002

Iwi/hapū:

$$
\begin{aligned}
& \text { Ngāti Awa* } \\
& \text { Ngāti Tamatera* } \\
& \text { Ngāti Raukawa* } \\
& \text { Ngāti Toa Rangatira* } \\
& \text { Ngāi Te Rangi* } \\
& \text { Ngāti Paoa* } \\
& \text { Waikato* } \\
& \text { Ngāi Tumatakokiri* } \\
& \text { Waitaha (Te Arawa)* }
\end{aligned}
$$

Keywords:

Letters

Narrative 
Waiata

Abstract: This volume contains copies of letters in Māori about land titles, relations between Māori and European settlers, loss of land. The letters date from 1842 to 1870 and many have translations, by Shortland. Contributors include: Hauauru Taipari (Ngāti Awa), Hou, Te Awe and Taraia (Ngāti Tamatera), Ngarara, Matene Te Whiwhi (Ngāti Raukawa and Ngāti Toa Rangatira), Rawiri Kingi Puhirake (Ngāi Te Rangi), a group from Ngāti Paoa, Wiremu Te Wheoro (Waikato), and Moeroa Paretaura, Pio Te Rongotoa, Wiremu Te Whareiro and Mauritiri Te Kuorehua (of Waitaha ki Te Arawa). There is also a narrative about bereavement with a waiata, from Ngāi Tumatakokiri.

25

Collector: Shortland, Edward

Year: 1844-45

Title: Copies of letters and papers relating to problems at Heretaunga and Port Nicholson

Collection Title: Shortland, Edward: papers (ARC-0020)

Reference Number: MS-0489/001

Iwi/hapū:

Ngāti Toa Rangatira*

Ngā Puhi*

Ngāti Rangatahi

Ngāti Tama

Pākehā*

Keywords:

Letters

Abstract: This item comprises a collection of letters exchanged between Te Rauparaha, Te Rangihaeata, George Clarke (Chief Protector of Aborigines) and Major Richmond concerning the continued occupation by Ngāti Rangatahi and Ngāti Tama of land at Heretaunga, in the Hutt Valley, which Te Rauparaha and Te Rangihaeata had signed over to the New Zealand Company. Some of these letters have been translated into English, apparently by Shortland. There is also a letter from Hone Heke (dated May 21st 1845) to the Governor protesting the ransacking of Kororareka being blamed on him and his people, who 'only cut down the flagpole', and a map of Muriwhenua (the Far North). There are also accounts of two conferences concerning the Heretaunga situation, and a diagram of a woman's moko.

\section{6}

Collector: Shortland, Edward

Year: 18--

Title: Notes on the Melanesian language, waiata and the whakapapa of Ngāti Awa

Collection Title: Shortland, Edward: papers (ARC-0020)

Reference Number: MS-0489/003

Iwi/hapū:

Ngāti Awa*
General* 


\section{Keywords:}

\section{Māori Language - grammar}

Wetereo

Karakia

Waiata

Whakapapa

Abstract: This item contains comprehensive grammatical notes on Melanesian language, with some comparisons with Māori. There is also a collection of karakia relating to childbirth, psychological illness, makutu, breastfeeding, naming a child. There are also karakia relating to a narrative about a woman taken by the patupaiarehe (fairy folk). The item also contains a number of waiata and a whakapapa from Ngāti Awa.

27

Collector: Shortland, Edward

Year: 1863

Title: Letter book containing correspondence relating to Shortland's tenure as civil commissioner

Collection Title: Shortland, Edward: papers (ARC-0020)

Reference Number: MS-0489/004

Iwi/hapū:

Ngāti Hauā

Ngāti Mutunga

Waikato*

Pākehā

General*

Keywords:

Letters

Whaikōrero

Abstract: This letter book, although mostly in English, does contain some letters in Māori. There is a letter from Rotoehu; Rapata te Arakai's account of speeches made at a hui in Ohinepouri (on the Waihou) with translations by Shortland; a report of a hui at Kawakawa (near Taupo, not the Northland Kawakawa) with speeches by Piti (Wiremu Piti Pomare, Ngāti Mutunga), Te Moananui (Meha, a Hauraki chief), Patene Puhata; a letter in Māori written by Shortland; and a narrative (in English) about Hauraki which includes sections in Māori.

28

Collector: Shortland, Edward

Year: 18--

Title: Notes on language, waiata, whakatauki, proverbs, customs and ceremony

Collection Title: Shortland, Edward: papers (ARC-0020)

Reference Number: MS-0489/005

Iwi/hapū:

Ngāti Hauā*

Ngāti Toa Rangatira* 
Keywords:

General*

Māori language - glossaries, vocabularies, etc

Māori language - pronunciation

Papakupu

Whakahua

Whakataukī

Waiata

Haka

Karakia

Karanga

Abstract: This folder contains a number of whakatauki, with translations, waiata, including waiata whaiaipo, waiata tangi, waiata aroha, and haka including peruperu, ngeri, oriori, harikai. There are translations and explanations supplied for some. Contributors include: Te Rauparaha, Te Waharoa, and Raunikara. There are also examples of karakia and karanga, with explanations, as well as descriptions of rituals to do with death and pregnancy/childbirth. The first lines of the waiata are listed on the Hākena database. Also included in this item is a table comparing the vocabulary of Māori, English, Tahitian and Hawaiian, together with some notes on pronunciation.

\section{9}

Collector: Shortland, Edward

Year: 1860-1880

Title: Letters from John White and William Thompson and papers including a funeral hymn, language notes, whakapapa, waiata and list of chiefs from the canoe 'Tainui'

Collection Title: Shortland, Edward: papers (ARC-0020)

Reference Number: MS-0599/001

Iwi/hapū:

Ngāti Hauā*

Waikato*

Taranaki*

Ngāti Porou*

General*

Keywords:

Maori language - glossaries, vocabularies, etc

Papakupu

Whakapapa

Waiata

Letters

Abstract: As the title suggests, this item contains whakapapa, waiata tangi, himene nehu tüpāpaku (funeral hymn). One waiata is from Taranaki, another is attributed to Te Waharoa and another is from Ngâti Porou. There are also vocabulary lists of fish which occur in the Waikato and trees (with botanical names). Also included is an annotated copy of a document entitled 'Ki te motu katoa'. This is a printed document which sets out to "put the deeds of Waikato in front 
of the entire land for each $i w i$ to decide whether they were right or wrong" (my translation). This document ends "Te Tari, Akarana, Aperira 10, 1863". It is unclear who or what Te Tari may be, but it could be the Ringatū tohunga Puke Tari.

30

Collector: Shortland, Edward

Year: 18--

Title: Papers including Tohi's whakapapa, waiata, karakia, whakataukī and Maori language notes.

Collection Title: Shortland, Edward: papers (ARC-0020)

Reference Number: MS-0599/002

Iwi/hapū:

Ngāti Raukawa*

Ngāti Ranginui*

Ngāti Whakaue*

Pākehā*

General*

Keywords:

Waiata

Haka

Whaikōrero

Whakapapa

Narrative

Abstract: There are a large number of waiata contained in this folder, gathered from various $i w i$. Iwi that can be identified are listed above. Names of subjects and composers are recorded for some, but most are unattributed. Composers include Upokoiti (Ngāti Raukawa). The item also contains three narratives about haka, one by Tarahawaiki Potatau, plus letters in Māori by Te Kewene (iwi unknown), Aihepene Kaihau (iwi unknown), and Shortland himself, a second language learner of Māori. There is also a whakapapa of Ngāti Ranginui, a whakapapa of Tohi Te Ururangi (Ngāti Whakaue), and a copy of a whaikōrero.

\section{Section 2: MS-1166 Collection}

This collection is not well provenanced. The Hākena database records: 'there is no depositing information about this collection. The shelf list card reads 'includes papers in Maori and about the Maoris (sic) collected from Edward Shortland, and documents relating to pioneer European occupation in Otago'. It is not arranged with the Shortland collection, so is recorded separately 
here also. This small collection would certainly benefit from further research into the origins of the manuscripts.

31

Collector: (?), Shortland

Year: 1832-1871

Title: Land deeds, particularly signed by George Clarke

Collection Title: Collection of papers relating to Maori and the Maori language (MS-1166)

Reference Number: MS-1 166/001

Iwi/hapū:

Ngā Puhi*

Pākehā*

Keywords:

Letters

Legal documents

Abstract: This item contains Land Deeds, purchases and correspondence to George Clarke from a number of people of the Far North. Items detail purchases and lists of items exchanged for land. All the Land Deeds seem to be in George Clarke's favour and written by him.

Correspondents include: Kaitara, Taoho, Tarapata, Paua, Tane King, Matariki, Parau, Hori Waru, Eruera Paru, Huarahi, Aparahama, Wiremu Hoete, Rewa, and many more. A full list of names is held within the folder. Pākehā correspondents include: George Clarke, William Puckey, Richard Davis, and Joanna Bloomfield. Places mentioned include; Taiamai, Waimate, Kaikohe, Moka, Pokehemo.

32

Collector: (?), Shortland

Year: n.d.

Title: 'Words and sentences in the New Zealand Language, collected by Mr. John King' Collection Title: Collection of papers relating to Maori and the Maori language (MS-1166)

Reference Number: MS-1166/003

Iwi/hapū:

General*

Keywords:

Māori language - glossaries, vocabularies, etc

Māori language - grammar

Wetereo

Papakupu

Abstract: These Māori language notes, compiled by John King, include examples of an extensive range of different phrase types. There is also a list of time phrases (pp 14-19) and vocabulary lists. King's orthography is interesting, as he writes ' $r$ ' as' $d$ ' and consistently confused the grammar particles 'he' and 'e'. 
Collector: (?), Shortland

Year: n.d.

Title: 'Vocabularies and translations in the New Zealand Language by Rev. John Butler'

Collection Title: Collection of papers relating to Maori and the Maori language (MS-1166)

Reference Number: MS-1166/004

Iwi/hapū:

$$
\text { General* }
$$

\section{Keywords:}

\section{Place names}

Abstract: This item contains a list of people's names (pp1-22) and place names (pp23-27), with glosses. The people's names do not seem to refer to any particular people, but are more like a glossary of the meanings of names. There is also a list of chiefs and their residences (pp28-30) and a list of tribes with glosses and the names of chiefs (pp31-32). The glosses are interesting in that they seem to represent Butler's idea of what the names may mean rather than any authoritative translation, for example: Te Roroa= the great length; Te Wai Ariki = the Priest's water. The folder also contains the Lord's Prayer and two other prayers, plus the Ten Commandments, in Maori (pp33-35). Butler's orthography is interesting in that he represents the Maori ' $r$ ' as' $d$ ', and does not distinguish ' $n$ ' and 'ng'. Much of his spelling would be considered incorrect in modern Māori, for example” Nae Tamatea (Ngāi Tamatea), Na Te Maru (Ngāti Maru).

\section{4}

Collector: (?), Shortland

Year: 1842-1882

Title: Letters to Shortland and Major Richmond, with notes on the Maori language

Collection Title: Collection of papers relating to Maori and the Maori language (MS-1166)

Reference Number: MS-1 166/005

Iwi/hapū:
Taranaki*
Te Āti Awa
Ngāti Toa Rangatira*
Tuhourangi*
Muaūpoko*
Te Arawa*
Ngāti Whakaue
Ngāti Tama
Ngāti Rangatahi
Pākehā*

Keywords:

Names

Letters

Whakapapa 
Waiata

Whakataukī

Abstract: This eclectic item contains letters to Shortland and Richmond as well as information about tribes and their chiefs, and some Māori language notes. The iwi lists relate to Taranaki and Wellington and include $i w i$ names, the places they inhabit and their chiefs. There is also whakapapa of Matene Te Whiwhi (Ngāti Toa), Maui Pomare (Taranaki). Also included are letters from Te Kepa (Tuhourangi); Haora Tipa, Tamati Tangi Te Ruru and Te Ratu (Muaūpoko), enclosing waiata; from Ringori Te Ao (Te Arawa); Te Rauparaha; Taraia (Hauraki). There are also letters by Shortland written in Māori.

35

Collector: (?), Shortland

Year: 1863-1871

Title: Letters to Shortland and miscellaneous papers relating to Maori

Collection Title: Collection of papers relating to Maori and the Maori language (MS-1166)

Reference Number: MS-1166/006

Iwi/hapū:

Te Arawa

Ngāti Raukawa*

Waikato*

Keywords:

Whakapapa

Waiata

Letters

Abstract: Much of this item is in English, but there are letters in Māori to Shortland as well as waiata, one of which is attributed to Tama Te Kapua. There are also whakapapa for Ngāti

Raukawa, Ranginui and Papatūānuku, Tainui waka and a whakapapa that starts with Tuheitia.

36

Collector: (?), Shortland

Year: n.d.

Title: Papers relating to whakapapa and Maori mythology

Collection Title: Collection of papers relating to Maori and the Maori language (MS-1166)

Reference Number: MS-1166/007

Iwi/hapū:

Te Rarawa

Ngā Puhi

Ngāti Whātua

Waikato

Ngāti Maru

Ngāti Awa

Ngāi Te Rangi

Ngāti Whakaue 


\section{Ngāti Tūwharetoa \\ Ngāi Tūhoe \\ Te Whakatohea}

Keywords:

Karakia
Whakapapa
Narrative
Waiata

Abstract: This item contains karakia, whakapapa and narratives from a range of tribal areas. All the whakapapa appear to cover the period of gods and demigods, one starting with Te Pō, to Hinetītama, to Ruamano, to Tangaroanuiawhatu, to Ngarutuatahi, Ngarutuarua and so on, ending with Te Ritooterangi. There is also a loose-leaf with a whakapapa from Tamatea showing connections to the people of Kahungungu, Heretaunga, Te Hapuku and Te Moananui. There is also whakapapa supplied by Henare Pakura of Mohaka showing other descent lines from Tamatea, and a whakapapa of Tiakiwai. Pan-tribal myths are also covered, such as Māui, Mahuika, Ranginui and Papatūānuku and Hinenuitepo. No particular dialects could be identified, but some of the $i w i$ covered are listed above.

37

Collector: (?), Shortland

Year: n.d.

Title: Collection of papers relating to Maori and the Maori language

Collection Title: Collection of papers relating to Maori and the Maori language (MS-1166)

Reference Number: MS-1166/008

Iwi/hapū:

Waikato*

Ngāti Rangi

Ngāti Hauā

Ngāti Koi

General*

Keywords:

Haka

Whakapapa

Abstract: This item contains many whakapapa, including from Ngāti Rangi and Ngāti Hauā. There is a whakapapa of Tuheitia and Ata and the line down to Wiremu Tamihana Te Waharoa, one for Romai and Pukai, one for Te Toki and Hinerape (Ngāti Koi), and the ancestral lines of Mahaki from whom Ngāti Rangi are descended. There are also lists of recently deceased with names of descendents, and a haka. Also contained in this folder is a letter to Hone Wepihana from Nahaki Te Kuri (Ngāti Maniapoto?). 
Collector: (?), Shortland

Year: 1836-1866

Title: Miscellaneous papers 1836-1866

Collection Title: Collection of papers relating to Maori and the Maori language (MS-1166)

Reference Number: MS-1166/011

Iwi/hapū:

Waikato*

Ngāti Toa Rangatira*

Keywords:

Ngāti Rangiwewehi*

Letters

Waiata

Abstract: This item contains correspondence, much of it addressed to Willoughby Shortland. Letter writers include: Wiremu Pakau Tarapipipi (Waikato), Tamihana Te Rauparaha (Ngāti Toa), and Wiremu Maehe Te Rangikaheke (Ngāti Rangiwewehi). Many of these letters deal with disputes between Māori and Pākehā. There is also a waiata composed by Tarapipipi.

\section{Section 3: The Beattie Collection}

Known as Herries, Beattie was a bookkeeper, journalist, historian, ethnologist and bookseller. He had strong interests in literature, natural history, and Otago and Southland history. After running a bookshop in Waimate until 1939, he devoted his life to writing and publication. His collecting activities were almost exclusively in the South Island.

\section{9}

Collector: Beattie, James Herries

Year: 1920

Title: Notebook relating to warfare between Maori within the South Island

Collection Title: Beattie, James Herries: Papers (ARC-0162)

Short Title: Notebook relating to warfare between Maori within the South Island

Reference Number: MS-0147

Iwi/hapū:

Kāi Tahu*

Ngāti Toa Rangatira

Kāti Mamoe

Kāti Kuri

Keywords: 
Narrative

Abstract: This notebook contains Beattie's notes from a manuscript left to him by T.E.Green of Tuahiwi (Kaiapoi). Green was one of the informants (along with Tikao) for Cowan's Folk Tales of the Port Hills. There are narratives of three South Island battles, written by Natanahira Waruwarutu. The first narrative is of a battle between Kāti Mamoe and Kāti Kuri (hapū of Kāi Tahu); another is of a battle between Te Rehu and Te Kaapo Te Kapatu, at Mapoutahi, and the third is a history of the destruction of Kaiapoi by Te Rauparaha.

40

Collector: Beattie, James Herries

Year: 1920

Title: Record of interviews with South Island Maori, entitled, 'The Maori in Murihiku', sections 16 to 24

Collection Title: Beattie, James Herries: Papers (ARC-0162)

Reference Number: MS-0181/002

Iwi/hapū:

Kāi Tahu*

Keywords:

Māori language - glossaries, vocabularies, etc

Papakupu

Abstract: This item comprises mostly notes in English on a variety of subjects, the headings for which are listed on the Hākena database. There is, however, a section on relationship terms.

41

Collector: Beattie, James Herries

Year: 1920

Title: Record of interviews with Maori in Canterbury, sections 23 to 28

Collection Title: Beattie, James Herries: Papers (ARC-0162)

Reference Number: MS-0181/005

Iwi/hapū:

Kāi Tahu

Keywords:

Māori language - glossaries, vocabularies, etc

Papakupu

Abstract: This folder contains notes on a variety of subjects, headings for which are available on the Hākena database. Māori language material includes whakataukī (part Section XXV), notes on the origin of place names (part Section XXVI), relationship terms for the people of Rāpaki, Tuahiwi, Taumutu and Nelson (Section XXVII) and word lists, including words for body parts in Nelson, Canterbury and Murihiku (Section XXVIII). 
sons 


\author{
Kāi Tahu* \\ Keywords: \\ Waitaha (Te Waipounamu) \\ Narrative \\ Karakia
}

\begin{abstract}
This item contains names of signatories to the Otago Block sale, place names on the Otago peninsula and in Canterbury, a list of waka and their captains, and a number of narratives, including two about the ancestor Pou. One of the Pou stories is about him riding the oceans on the back of the Great Bird of Tāne. There is also a karakia included. According to accompanying notes, the narratives are copied from a manuscript by Pita Piper of Rāpaki, dictated to him by old men including Taare Te Maiharoa and Hoani Kahu.
\end{abstract}

Notes: Preservation copy issued in place of original

\title{
45
}

Collector: Beattie, James Herries

Year: 1880

Title: Copied extracts from a notebook of John Kahu

Collection Title: Beattie, James Herries: Papers (ARC-0162)

Reference Number: MS-582/F/11 (PC-0209)

Iwi/hapū:

Kāi Tahu*

Kāti Mamoe

Keywords:

Whaikōrero

Letters

Abstract: This item, as the title suggests, contains material copied by Beattie from a John Kahu notebook. There are names of food sources, wähi tapu, permanent dwelling sites, urupa and flax gathering sites and other culturally significant sites. Māori language material includes a kōrero by Hori Kerei Taiaroa at a Kāi Tahu/Kāti Mamoe rünanga, urging attendees to express their thoughts about land sales and Government actions. This section also includes a list of the food had at the hui. There is also a document giving Taiaroa and his colleagues permission to report to the Government on behalf of the committee, and then to the English parliament if the Government's response is not satisfactory.

Notes: Preservation copy issued in place of original.

See also: $M S-582 / F / 14 / a($ Item 46).

46

Collector: Beattie, James Herries

Year: c. 1880-1882

Title: Notebook of John Kahu

Collection Title: Beattie, James Herries: Papers (ARC-0162) 
Reference Number: MS-582/F/14/a (PC-0232)

Iwi/hapū:

Kāi Tahu*

Kāti Mamoe

Keywords:

Letters

Whaikōrero

Abstract: This is the original manuscript on which MS-582/F/11 is based.

Notes: Preservation copy issued in place of original.

See also: Items 45 and 47.

47

Collector: Beattie, James Herries

Year: 1880-1884

Title: Notebook containing numerous accounts pertaining to the South Island

Collection Title: Beattie, James Herries: Papers (ARC-0162)

Reference Number: MS-582/F/17 (PC-0127)

Iwi/hapū:

Kāi Tahu

Kāti Tuhaitia

Keywords:

Māori language - glossaries, vocabularies, etc

Letters

Narrative

Abstract: This item is copied from John Kahu's notebook. It contains letters about land issues from Tame Parata and Te Kooti Te Rato. There is also a vocabulary list, and narratives about South Island $i w i$ and hapu, mainly Kāti Tuhaitia. The item also contains whakatauki.

Notes: Preservation copy issued in place of original.

See also: MS-582/F/14/a (Item 46).

48

Collector: Beattie, James Herries

Year: 1864-1918

Title: Papers relating to Kai Tahu and Waitaha

Collection Title: Beattie, James Herries: Papers (ARC-0162)

Reference Number: MS-582/F/18

Iwi/hapū:

Kāi Tahu*

Waitaha (Te Waipounamu)

Keywords:

Whakapapa 
Waiata

Abstract: A note by Beattie at the beginning of this item states that all but one or two items were written by 'aged and full-blooded Maoris (sic)'. Contents include a number of Kāi Tahu whakapapa, including one for Rawiri Te Uwauwa. There are also a number of waiata, including an 'ancient' oriori from Stewart Island and a waiata by Te Muru for Rupena Kuri.

\section{Section 4: The Roberts Collection}

William Henry Sherwood Roberts (1834-1917) immigrated to New Zealand on the 'John Phillips' in 1855 . He had a cattle run near Invercargill and a sheep run at Tapanui, both of which he lost. Roberts then became an auctioneer and agent in Oamaru, where he also undertook public service roles. He published several historical works, including 'Maori Nomenclature', and published collections in the daily press. The items from the Roberts Collection listed are predominantly concerned with place names of the South Island. They are included here because of the language features revealed.

49

Collector: Roberts, W.H.S.

Year: c. 1909

Title: Notebooks entitled 'Maori nomenclature', volumes 1 to 3

Collection title: Roberts, W.H.S.: Papers (ARC-0057)

Reference Number: MS-1206/003

Iwi/hapū:

Kāi Tahu*

Keywords:

Place names

Abstract: This item consists of three volumes of notes concerning the naming of South Island localities. Volume 1 covers the Inland Lakes and the North Otago Coast. Volume 2 covers Oamaru and south to Dunedin. Volume 3 covers the Otago Peninsula, Dunedin and the Taieri Plains.

\section{0}

Collector: Roberts, W.H.S.

Year: c.1909 
Title: Notebooks entitled 'Maori nomenclature', volumes 4 to 7

Collection title: Roberts, W.H.S.: Papers (ARC-0057)

Reference Number: MS-1206/004

Iwi/hapū:

Kāi Tahu*

Keywords:

Place names

Abstract: This item consists of 4 notebooks, with extensive coverage of the origins of place names in Otago and Southland. Volume 4 covers Clutha and the Catlins, volume 5 covers Gore, Invercargill, Bluff, Fouveaux Strait and Stewart Island, volume 6, Stewart Island, the Muttonbird Islands, Te Waewae Bay and Te Anau, and volume 7 is the Western Lakes.

51

Collector: Roberts, W.H.S.

Year: c. 1902

Title: Notebooks entitled 'Maori nomenclature; names in Canterbury; interesting information Collection title: Roberts, W.H.S.: Papers (ARC-0057)

Reference Number: MS-1206/005

Iwi/hapū:

Kāi Tahu*

Keywords:

Māori language - pronunciation

Whakahua

Abstract: There are two notebooks in this item. Both contain information on Canterbury place names. There are also two articles entitled 'How names should be pronounced' which also discusses how pronunciation has been corrupted over time, and "How words have changed'.

\section{2}

Collector: Roberts, W.H.S.

Year: c. 1902

Title: Notebooks entitled 'Maori nomenclature; names in Canterbury; interesting information, numbers 7-9

Collection title: Roberts, W.H.S.: Papers (ARC-0057)

Reference Number: MS-1206/006

Iwi/hapū:

Kāi Tahu*

Keywords:

Place names

Māori language - pronunciation

Whakahua

Abstract: This item consists of three notebooks with handwritten notes and annotated newspaper clippings about place names in Canterbury and pronunciation. They appear to be a series of drafts of the articles in MS-1206/005. 
See also: MS-1206/005 (Item 51).

53

Collector: Roberts, W.H.S.

Year: 1903-1912

Title: Volume entitled 'Marlborough and Canterbury Maori nomenclature; the Maori language; how names should be pronounced'

Collection title: Roberts, W.H.S.: Papers (ARC-0057)

Reference Number: MS-1206/007

Iwi/hapū:

Kāi Tahu*

Keywords:

Place names

Abstract: This item contains heavily annotated versions of the article 'How names should be pronounced' from MS-1206/005, and 'Maori names of places in the Provincial District of Marlborough'. There are also a number of letters to the editors of newspapers about Māori nomenclature in the South Island.

See also: MS-1206/005 (Item 51).

54

Collector: Roberts, W.H.S.

Year: n.d.

Title: Notebooks entitled 'Marlborough Maori nomenclature'

Collection title: Roberts, W.H.S.: Papers (ARC-0057)

Reference Number: MS-1206/008

Iwi/hapū:

Kāi Tahu*

Keywords:

Place names

Abstract: This item contains three notebooks of handwritten notes and annotated newspaper clippings.

See also: MS-1206/007 (Item 53).

55

Collector: Roberts, W.H.S.

Year: n.d.

Title: Notebooks entitled 'Westland Maori nomenclature; interesting information'

Collection title: Roberts, W.H.S.: Papers (ARC-0057)

Reference Number: MS-1206/009 
Iwi/hapū:

Keywords:

$$
\text { Kāi Tahu* }
$$

Place names

Abstract: This item consists of annotated newspaper clippings on Māori nomenclature from Westland, Nelson and Golden Bay.

56

Collector: Roberts, W.H.S.

Year: n.d.

Title: Notebooks entitled 'Westland Maori nomenclature; interesting information; and other interesting information from the West Coast in the Provincial district of Nelson

Collection title: Roberts, W.H.S.: Papers (ARC-0057)

Reference Number: MS-1206/010

Iwi/hapū:

Keywords:

Kāi Tahu*

Place names

Abstract: This item consists of handwritten notes and draft newspaper articles about Māori place names of Westland, Nelson and Golden Bay.

See also: MS-1206/009 (Item 55).

57

Collector: Roberts, W.H.S.

Year: c. 1902

Title: Notebooks entitled 'Waitaki Maori nomenclature'

Collection title: Roberts, W.H.S.: Papers (ARC-0057)

Short Title: Notebooks entitled 'Waitaki Maori nomenclature'

Reference Number: MS-1206/012

Iwi/hapū:

Kāi Tahu*

Keywords:

Place names

Abstract: This item consists of two notebooks of notes and newspaper clippings concerning Māori place names of Waitaki.

58

Collector: Roberts, W.H.S.

Year: n.d.

Title: Notebook entitled 'Maori nomenclature; names of places in the middle island'

Collection title: Roberts, W.H.S.: Papers (ARC-0057) 
Reference Number: MS-1206/013

Iwi/hapū:

Kāi Tahu*

Keywords:

Place names

Abstract: This item contains notes on the origins of Māori place names in the Nelson region.

59

Collector: Roberts, W.H.S.

Year: 1907-1910

Title: Correspondence relating to Maori nomenclature

Collection title: Roberts, W.H.S.: Papers (ARC-0057)

Reference Number: MS-1206/027

Iwi/hapū:

Keywords:

Kāi Tahu*

Place names

Abstract: This item contains correspondence between Roberts and other scholars about his work on Māori place names. It also contains copies of Roberts' volumes on place names of Canterbury, the West Coast and Nelson, Marlborough and North Otago.

60

Collector: Roberts, W.H.S.

Year: 1899-1903

Title: Miscellaneous papers relating to Maori

Collection title: Roberts, W.H.S.: Papers (ARC-0057)

Reference Number: MS-1206/029

Iwi/hapū:

Kāi Tahu*

General*

Keywords:

Māori language - glossaries, vocabularies, etc

Papakupu

Place names

Abstract: This item consists mainly of notes on Māori place names - of Otago Lakes,

Canterbury Lakes, Westland Lakes, Nelson Lakes, and Auckland Lakes. It also contains 89 pages of vocabulary lists.

61

Collector: Roberts, W.H.S.

Year: 1896-1905

Title: Papers relating to Maori nomenclature, vol. 1 
Collection title: Roberts, W.H.S.: Papers (ARC-0057)

Reference Number: MS-1206/030

Iwi/hapū:

Kāi Tahu*

Keywords:

Place names

Abstract: First drafts of a number of articles on Māori place names of Port Chalmers, Dunedin, Otago Harbour, later published in newspapers.

62

Collector: Roberts, W.H.S.

Year: 1897-1914

Title: Papers relating to Maori nomenclature, vol. 2

Collection title: Roberts, W.H.S.: Papers (ARC-0057)

Reference Number: MS-1206/031

Iwi/hapū:

Keywords:

Kāi Tahu*

Place names

Abstract: This item contains the first editions of articles about Māori place names in Westland, Nelson, Marlborough and Canterbury.

63

Collector: Roberts, W.H.S.

Year: 1912

Title: Roberts, W. H. S. 'Maori nomenclature', Dunedin

Collection title: Roberts, W.H.S.: Papers (ARC-0057)

Reference Number: MS-1206/036

Iwi/hapū:

Kāi Tahu*

Keywords:

Place names

Abstract: An original edition of Roberts' booklet Māori nomenclature, Dunedin: Otago Daily Times, 1912. Includes place names from West Coast, Canterbury, Marlborough and Nelson.

64

Collector: Roberts, W.H.S.

Year: 1916-1922

Title: Scrapbooks relating to the Dunstan gold rush, the Maori language and early Otago

Collection title: Roberts, W.H.S.: Papers (ARC-0057)

Reference Number: MS-1206/037

Iwi/hapū:

General* 


\section{Keywords:}

Māori language - pronunciation

Whakahua

Abstract: This item contains copies of articles 'The Maori Language - pronunciation' and 'The Maori Language - changes'.

\section{Section 5: The Chapman Collection}

Sir Frederick Revans Chapman (1849 - 1936), was the first New Zealand-born supreme court judge. He studied law in London and practiced in Dunedin from 1872. He was also a law lecturer at the University of Otago from 1876-1878 and involved in civic politics as a city councilor. He was appointed President of the Court of Arbitration with the status of a Supreme Court Judge in 1903 and retained that post until 1907, when he assumed full work in the Supreme Court. The Chapman collection comprises mainly research papers collected for writing histories, primarily concerning Māori history and place names.

65

Collector: Chapman, Frederick Revans

Year: 1893-95

Title: Notebook entitled, 'Gazetteer, Maori names, South Island'

Collection title: Chapman, Sir Frederick Revans Papers (ARC-0019)

Reference Number: MS-0412

Iwi/hapū

Kāi Tahu*

Kāti Mamoe*

Keywords:

Waitaha (Te Waipounamu)

Place names

Narrative

Abstract: This item contains an extensive collection of place names from the South Island, mainly but not exclusively Otago and Southland. Much of the information was supplied by tame Parata. There are also letters to Chapman concerning place names, and copies of Roberts' newspaper articles on Māori nomenclature. 
66

Collector: Chapman, Frederick Revans

Year: 1889

Title: Notebook entitled, 'Field notes, South Island'

Collection title: Chapman, Sir Frederick Revans Papers (ARC-0019)

Reference Number: MS-0414

Iwi/hapū:

Keywords:

Kāi Tahu*

Place names

Abstract: This item contains notes on South Island place names. It also contains notes (in English) on the working of pounamu (greenstone) and the making of stone implements. The notebook also includes images of stone implements.

67

Collector: Chapman, Frederick Revans

Year: n.d.

Title: Notebook entitled, 'Notes on South Island place names, mostly in Otago'

Collection title: Chapman, Sir Frederick Revans Papers (ARC-0019)

Reference Number: MS-0416/001

Iwi/hapū:

Kāi Tahu*

Keywords:

Place names

Abstract: This is a notebook containing notes on Māori place names, mostly in Otago. The information was provided by Rawiri Te Maire, Tame Parata and Wetere Te Kahu.

68

Collector: Chapman, Frederick Revans

Year: n.d.

Title: Notebook

Collection title: Chapman, Sir Frederick Revans Papers (ARC-0019)

Reference Number: MS-0416/002

Iwi/hapū:

Keywords:

Kāi Tahu*

Place names

Abstract: This notebook contains information on place names provided by the Māori of Puketeraki (Karitane). 
69

Collector: Chapman, Frederick Revans

Year: n.d.

Title: Notebook

Collection title: Chapman, Sir Frederick Revans Papers (ARC-0019)

Reference Number: MS-0416/005

Iwi/hapū:

Kāi Tahu*

General *

Keywords:

Māori Language - Glossaries, vocabularies, etc

Papakupu

Place names

Abstract: This notebook contains more of Chapman's notes on place names, particularly in the South, as well as some notes on vocabulary.

70

Collector: Chapman, Frederick Revans

Year: n.d.

Title: Notebook entitled, 'Arai-Te-Uru 2nd book'

Collection title: Chapman, Sir Frederick Revans Papers (ARC-0019)

Reference Number: MS-0416/006

Iwi/hapū:

Kāi Tahu*

Keywords:

Place names

Abstract: This notebook contains notes on the origins of place names, mainly of Canterbury and coastal Otago, as they relate to the waka Arai-te-uru.

71

Collector: Chapman, Frederick Revans

Year: 1894

Title: Notebook entitled, 'Arai-Te-Uru and other matters'

Collection title: Chapman, Sir Frederick Revans Papers (ARC-0019)

Reference Number: MS-0416/015 (PC-0203)

Iwi/hapū:

Kāi Tahu*

Keywords:

Waiata

Narrative

Place names

Abstract: This item contains 21 waiata of various styles. Chapman's' note at the start states them to be from Waikouaiti, however, a note at the end says they are from Moeraki. It is possible there are some from each source. There is also a narrative in Māori about the waka Arai- 
te-uru and notes on the names of geographical features arising from the narrative.

Notes: Preservation copy issued in place of original

72

Collector: Chapman, Frederick Revans

Year: 1896

Title: Notebook containing notes on New Zealand history

Collection title: Chapman, Sir Frederick Revans Papers (ARC-0019)

Reference Number: MS-0416/016 (PC-0204)

Iwi/hapū:

Keywords:

Kāi Tahu*

Waiata

Narrative

Place names

Abstract: This item includes waiata contributed by Mrs. Hamiora Weka, and notes in Māori about the waka Arai-te-uru and places named after crew, contributed by Hoani Tipa. Mrs. Weka and Hoani Tipa are both from Moeraki.

Notes: Preservation copy issued in place of original

73

Collector: Chapman, Frederick Revans

Year: n.d.

Title: Notebook 'No. 1'

Collection title: Chapman, Sir Frederick Revans Papers (ARC-0019)

Reference Number: MS-0417/001

Iwi/hapū:

Keywords:

Kāi Tahu*

Place names

Abstract: This is another Chapman notebook containing place names associated with the waka Arai-te-uru.

74

Collector: Chapman, Frederick Revans

Year: 1890

Title: Notebook entitled, 'Early history, miscellaneous, Dunedin names'

Collection title: Chapman, Sir Frederick Revans Papers (ARC-0019)

Reference Number: MS-0426/002

Iwi/hapū: 


\section{Kāi Tahu*}

Keywords:

Place names

Abstract: This item also contains notes on place names, being rough notes for some of the material that later appeared in Chapman's gazetteer. There are also notes about Te Rauparaha's campaign in Kaiapoi and about Karetai, Tuhawaiki and Iwikau.

75

Collector: Chapman, Frederick Revans

Year: 1890

Title: Notebook entitled, 'Scrapbook may contain important notes [on] history and natural history'

Collection title: Chapman, Sir Frederick Revans Papers (ARC-0019)

Reference Number: MS-0426/003

Iwi/hapū:

Keywords:

Kāi Tahu*

Place names

Abstract: This item contains more notes on place names of the South. There are also notes (in English) comparing Māori with other cultures and notes about Māori stone implements.

76

Collector: Chapman, Frederick Revans

Year: 1890

Title: Notebook containing information on the history of Waikouaiti

Collection title: Chapman, Sir Frederick Revans Papers (ARC-0019)

Reference Number: MS-0426/004

Iwi/hapū:

Kāi Tahu

Waitaha (Te Waipounamu)

Keywords:

Whakapapa

Abstract: This notebook contains whakapapa relating to Moeraki Māori, including Waitaha lines.

\section{Section 6: The Wallscott Collection}

Louise Magdalene Teowaina Wallscott (1898 - 1999) was widely known as Aunt Magda. At the time of her death she was the oldest surviving member on Ngai Tahu's tribal roll. Her great 
grandfather was the eminent chief Karetai. As a young woman, she went to Te Waipounamu College for Maori girls in Christchurch, then trained as a teacher at Christchurch Teachers College. Her teaching career took her to Rakiura (Stewart Island), Bluff, Clifden and Invercargill before she returned to Dunedin to teach at the Otakou Native School. Miss Wallscott was a founding member of the Maori Women's Welfare League and also a founding member of the Araiteuru Cultural Club and made a huge contribution to having Araiteuru Marae built. She also took an active role at Otakou marae, where she held the position of secretary for more than 30 years. Other organisations Miss Wallscott was involved in included the Otakou Māori Committee, the Otago Māori Executive, National Council of Women and the YWCA. In 1960, she became the first Māori woman in Dunedin to be appointed a justice of the peace, and one of few Dunedin women to hold such an appointment. Much of her spare time was spent compiling family trees of Otago Māori and her knowledge of whakapapa (genealogy) was copious. She was also a skilled and prolific weaver and taught the skills to many. In 1990 she received an award from the Māori and South Pacific Arts Council for her contribution to weaving. Miss Wallscott also closely followed and supported the Ngāi Tahu claim process and testified several times before the Waitangi Tribunal. All of these interests are reflected in her papers.

77

Collector: Wallscott, Louise Magdelene Teowaina Year: n.d.

Title: Notebook entitled, 'Notes Otakou, Otago tenths'

Collection title: Wallscott, Louise Magdelene Teowaina: Papers

Reference Number: MS-2431/052

Iwi/hapū:

Kāi Tahu*

Kāti Mamoe

Keywords: 
Whakapapa

Place names

Māori Language - Glossaries, vocabularies, etc

Papakupu

Abstract: This notebook contains a wide variety of content, details of which are available on the Hākena database. Items of interest in terms of this bibliography are the meanings of several place names and names of lakes and hills around Otākou, and glossaries of trees and shrubs. The notebook also contains a number of Kāi Tahu whakapapa.

78

Collector: Wallscott, Louise Magdelene Teowaina

Year: 1980's

Title: Leaflets and pamphlets relating to Maori language, place names, land and the Treaty of Waitangi

Collection title: Wallscott, Louise Magdelene Teowaina: Papers

Reference Number: MS-2431/059

Iwi/hapū:

General*

Keywords:

Māori Language - Glossaries, vocabularies, etc

Papakupu

Place names

Abstract: This item contains a number of leaflets and pamphlets. Of particular interest are: '40 common elements in Maori place names' by G.J. Griffiths, Otago Heritage Books, 1987; a vocabulary list; original wording of the Treaty of Waitangi with translations and discussion.

79

Collector: Wallscott, Louise Magdelene Teowaina

Year: n.d.

Title: Whakapapa information

Collection title: Wallscott, Louise Magdelene Teowaina: Papers

Reference Number: MS-2431/067

Iwi/hapū:

Kāi Tahu

Kāti Irakehu

Keywords:

Whakapapa

Abstract: This item contains a number of Kāi Tahu whakapapa. There are also details of a case for inheriting titi (mutton birding) rights. 
Collector: Wallscott, Louise Magdelene Teowaina

Year: 1973, 1075

Title: Letters from Syd Cormack requesting whakapapa information

Collection title: Wallscott, Louise Magdelene Teowaina: Papers

Reference Number: MS-2431/068

Iwi/hapū:

Kāi Tahu

Keywords:

Whakapapa

Abstract: This item includes drafts of whakapapa for Te Paki and Hauiau, Te Ihupupu and Raumotomoto, and Karetai.

81

Collector: Wallscott, Louise Magdelene Teowaina

Year: n.d.

Title: Whakapapa book

Collection title: Wallscott, Louise Magdelene Teowaina: Papers

Reference Number: MS-2431/070

Iwi/hapū:

Kāi Tahu*

Kāti Mamoe

Keywords:

Whakapapa

Place names

Abstract: This item contains several pages of Kāi Tahu and Kāti Mamoe whakapapa.

Whakapapa include; Tahu Potiki = Ihau, Paikea $=$ Tamaoruatia, Te Whakatitiro = Pipiriki,

Rakaiwakata $=$ Manawatakitu, Honekai $($ Kāi Tahu $)=$ Kohuai $($ Kāti Mamoe $)$, Pipi $=$ Kauo. There is also a list of place names around the Otago Peninsula.

82

Collector: Wallscott, Louise Magdelene Teowaina

Year: n.d.

Title: Whakapapa information

Collection title: Wallscott, Louise Magdelene Teowaina: Papers

Reference Number: MS-2431/072

Iwi/hapū:

Kāi Tahu

Kāti Mamoe

Keywords:

Whakapapa

Abstract: This notebook comprises several pages of Kāi Tahu whakapapa. There are whakapapa for Tahu Potiki and Tuhawaiki, as well as a number of whakapapa provided by Tiramorehu of Moeraki, including Wallscott and Russell whakapapa. 
83

Collector: Wallscott, Louise Magdelene Teowaina

Year: 1974

Title: Whakapapa book

Collection title: Wallscott, Louise Magdelene Teowaina: Papers

Reference Number: MS-2431/071

Iwi/hapū:

Kāi Tahu

Keywords:

Whakapapa

Abstract: This notebook contains whakapapa for the Karetai family.

84

Collector: Wallscott, Louise Magdelene Teowaina

Year: n.d.

Title: Copy of paper entitled, Names of hapu of Kai-Tahu tribe of Maori'

Collection title: Wallscott, Louise Magdelene Teowaina: Papers

Reference Number: MS-2431/074

Iwi/hapū:

Kāi Tahu*

Kāti Mamoe

Keywords:

Whakapapa

Abstract: This item contains photocopies of Misc-MS-424 and MS-402 listing hapū of Kāi

Tahu. There is also a whakapapa of Kāti Mamoe descendents beginning with Hekaia.

85

Collector: Wallscott, Louise Magdelene Teowaina

Year: n.d.

Title: Papers relating to the origin of Arai Te Uru canoe

Collection title: Wallscott, Louise Magdelene Teowaina: Papers

Reference Number: MS-2431/113

Iwi/hapū:

Kāi Tahu*

Keywords:

Narrative

Abstract: This item contains a narrative of the waka Arai-te-uru written in both English and Southern Māori. 
86

Collector: Wallscott, Louise Magdelene Teowaina

Year: 1983

Title: Papers relating to Harakeke and flax weaving

Collection title: Wallscott, Louise Magdelene Teowaina: Papers

Reference Number: MS-2431/124

Iwi/hapū:

General*

Keywords:

Māori Language - Glossaries, vocabularies, etc

Papakupu

Abstract: This item contains both published and unpublished material about flax, pingao and weaving. Of particular interest is the list of vocabulary relating to varieties of flax and flax preparation.

\section{Section 7: Miscellaneous items}

The following items are either single item collections or items from small collections. Where it is available, brief information on the collector is included in the abstract of the item.

87

Collector: Unknown

Year: n.d.

Title: Hauhau prayer book entitled 'Karakia o Te Hauhau'

Collection title:: Hauhau prayer book entitled 'Karakia o Te Hauhau'

Reference Number: Misc-MS-0175

Iwi/hapū:

Taranaki

Keywords:

Karakia

Abstract: This item consists of a Hauhau Prayer book, written by Te Ua Haumene. Haumene was the founder and prophet of the Hauhau religion.

88

Collector: Belsham, Ulva L., Mrs.

Year: 1929-1930

Title: Notebook of Southern place names, waiata and vocabulary.

Collection title:: Belsham, Ulva L., Mrs. Papers

Reference Number: Misc-MS-0933/002 
Iwi/hapū:

Kāi Tahu*

Kāti Mamoe*

Keywords:

Whanganui*

Māori Language - Glossaries, vocabularies, etc

Papakupu

Waiata

Place names

Abstract: Mrs. Belsham is a great granddaughter of William Cameron, and a descendant of Eruera Poko Cameron. This notebook contains notes on Bluff place names, collected from local Māori and transcribed by Eruera P. Cameron (August 1929), as well as a list of place names on Ruapuke Island. There are also a number of waiata from the Bluff area, including waiata aroha, waiata tangi, waiata takitaki and oriori. One is attributed to Te Peehi's wife after he was killed at Kaiapoi, and another attributed to Rangatiki for her husband Tauarangi killed at Ruapuke. There is also a waiata takitaki by the women of Whanganui to Te Rauparaha. There are also vocabulary lists for clothing, the fingers of the hand, months and seasons, attributed to 'an old native of Murihiku'. The notebook also has vocabularies relating to plant life; insects, worms, lizards and animals; eels and eeling; sea creatures; shells and shellfish and birds. The notebook also contains a list of Canterbury names for birds.

89

Collector: Betts, F.A., Dr.

Year: 1846

Title: Betts, F.A., Dr: He waiata

Collection title:: Betts, F.A., Dr: He waiata

Reference Number: Misc-MS-0945

Iwi/hapū:

Genera*

Keywords:

Waiata

Haka

Abstract: This notebook contains a number of waiata and haka collected by Betts. Iwi and composers are not listed. The first lines of each waiata are listed on the Hākena database.

90

Collector: Wast family

Year: 1924

Title: Wast family: Family notebooks

Collection title:: Wast family: Family notebooks

Reference Number: Misc-MS-1942

Iwi/hapū:

Kāi Tahu* 


\section{Kāti Mamoe*}

Keywords:

Whakapapa

Narrative

Abstract: Abram (or Abraham) Wast was a Russian Finn who settled in Stewart Island and married Tini (or Jane) Hamiro. The name is correctly spelt with an umlaut over the "a". These notebooks are believed to have bel;onged to Tini and her sisters. They were lodged by a family member. There are four note books, each of which seems to cover much of the same material. They contain whakapapa charts with Kāi Tahu and Kāti Mamoe connections. Names mentioned include; Tuhawaiki, Tuahuriri, Huirapa, Tahupotiki, Tuhaitara, and Korako. There is also a brief narrative, in Māori, about a cannibal feast avenging the death of Hakai.

91

Collector: Bull family

Year: 1864-1935

Title: Bull family Papers

Collection title: Bull family Papers

Reference Number: Misc-MS-1734

Iwi/hapū:

Kāti Mamoe*

Kāi Tahu*

Keywords:

Letters

Legal documents

Abstract: This item contains papers relating to the Bull family, Mutton (Tîtī) Island rights and land ownership in Southland, including letters, land receipts, succession application forms. Many of these documents are written in Māori.

Notes: Partially restricted. Access to the papers relating to the Bull family requires the written permission of Tamatea Bull.

92

Collector: Ruatapu, Mohi

Year: 1875

Title: [Mohi Ruatapu]: manuscript

Collection Title: [Mohi Ruatapu]: manuscript

Reference Number: MS-0045/C (PC-0048)

Iwi/hapū:

Keywords:

Ngāti Porou*

Whakapapa

Karakia

Narrative

Abstract: This is a small volume containing whakapapa, waiata and myths and narratives of 
Ngāti Porou, all in Māori. It is believed to have been written by Mohi Ruatapu, a tohunga of Ngāti Porou and has been transcribed and translated by Anaru Reedy (Ngā Kōrero a Mohi Ruatapu translated, edited and annotated by Anaru Reedy, Canterbury University Press, 1993). Notes: Preservation copy issued in place of original.

93

Collector: Hall, F.; Williams, H.

Year: 1839-1900

Title: Missionary letters \&c, F Hall 1821, H. Williams 1864

Collection Title: Missionary letters \&c, F Hall 1821, H. Williams 1864

Reference Number: MS-0053

Iwi/hapū:

General

Te Roroa*

Keywords:

Letters

Abstract: This item contains a total of 150 letters, some written by Frances Hall to James and Charlotte Kemp, but most written to George Clarke in his role as Protector of Aborigines. Three documents are written in Māori: Document no. 38 is dated 1842 and contains the address to the prisoner in the case of Queen versus Maketu, explaining the charge and court processes; Document 67. dated 1845, is a letter from Te Aro about a dispute over goods on the steamer Tory (accompanied by a translation by E. Davies); and document 146, c.1990, is a letter from Hone Peti of Waimate (Te Roroa) to George Clarke, including narratives of some trips they had together and other shared memories (accompanied by a translation).

94

Collector: Unknown

Year: 1863-1864

Title: Unknown: Papers relating to Māori

Collection Title: Unknown: Papers relating to Māori

Reference Number: MS-0152

Iwi/hapū:

Taranaki*

Ngāti Awa*

Whakatohea*

Ngāti Rangiwewehi*

Pākehā*

Keywords:

Letters

Narrative

Abstract: This item contains a large number of letters written during the time of the Land Wars in the Waikato and Taranaki, and describing grievances. Most of the letters are written in Māori. Letter writers include: a group from Taranaki writing to Rewi Maniapoto and Wiremu Kingi; a 
group from Ngāti Awa and Te Whakatohea; Wiremu Maihi (Te Rangikaheke - Rangiwewehi) asking the Māori of Maketu and Tauranga to stay and guard their own lands rather than going to support Whanganui and Napier; General Cameron (Pākehā); Aihe Pene Kaihau of Awhitu; Wi Hera; Timoti Tekaka (Whakatohea); Wiremu Kingi (Te Rangitake - Ngāti Awa). There are also other documents in Māori: description of changes in tikanga of Te Arawa and Ngāti Awa as a result of contact with Pākehā; narrative of a journey to Te Whaiti; diary entry about a family taken prisoner at Paparoa; and a Code of Laws listing 33 offences and the punishments.

95

Collector: Rangikaheke, Te

Year: 1880 's

Title: Te Rangikaheke: Commentary on Maori poems and mythology

Collection Title: Te Rangikaheke: Commentary on Maori poems and mythology

Reference Number: MS-0158

Iwi/hapū:

General

Ngāti Rangiwewehi*

Ngāti Toa Rangatira*

Ngāti Tūwharetoa*

Te Arawa*

Te Āti Awa

Keywords:

Waiata

Haka

Abstract: Wiremu Maihi Te Rangikaheke (? - 1896) was a Ngāti Rangiwewehi leader and scholar. This item is a typescript of material by Te Rangikaheke with commentary on waiata in Grey's Nga Moteatea me nga Hakirara. Contributors include: Te Rangikaheke, Wharepouri, Rangi Topeora, Te Rangihaeata, Te Heuheu Tukino III (Iwikau), Mokonui-a-rangi and Te Umairangi.

96

Collector: Wohlers, Johann Friedrich Heinrich

Year: 1874

Title: Papers on Maori mythology

Collection Title: Collected papers of and relating to Johann Freidrich Heinrich Wohlers (ARC0434)

Reference Number: MS-0234

Iwi/hapū:

Kāi Tahu*

Kāti Mamoe

Pākehā*

General*

Keywords: 
Narrative

Abstract: Wohlers, Johann Friedrich Heinrich (1811-1885) was a German national who immigrated to New Zealand in 1842 as a representative of the North German Missionary Society. Wohlers arrived on Ruapuke Island 17 May 1844, where he established a mission. He was also visiting pastor to Stewart Island, and the Chairman of the first Committee of Management of Ruapuke School, where he also taught prior to his death. This item contains handwritten manuscripts by a range of different people, including Wohlers himself. Many are either in Māori or both Māori and English. All are narratives of one sort or another about mythology, battles at Moeraki, Kaiapoi and Waikouaiti areas, and tikanga.

97

Collector: Thomson, George Craig

Year: n.d.

Title: Note in Maori from Karetai

Collection Title: Thomson, George Craig: papers relating mostly to the early history of Otago (ARC-0055)

Reference Number: MS-0438/163

Iwi/hapū:

Kāi Tahu*

Keywords:

Letters

Abstract: This item is a brief note (letter) to Te Raki from Karetai about a sale.

98

Collector: Paiki, Hemi

Year: 1883-1884

Title: Paiki, Hemi: Waiata

Collection Title: Paiki, Hemi: Waiata

Reference Number: MS-0715

Iwi/hapū:

Ngāti Ira*

Ngāti Porou*

General*

Keywords:

Waiata

Abstract: This item contains 13 pages of what appear to be financial accounts, followed by a number of waiata. Some of these waiata are attributed - to Huka Whanake (Ngāti Ira) and Te Kani-a-takirau (Ngāti Porou). There are also some signed TRM, possibly Te Ropiha Moturoa). Many others are unattributed.

99

Collector: Smith, Stephenson Percy 
Year: $1869-1910$

Title: Letters from Alexander Shand to Stephenson Percy Smith transcribed by unknown Collection Title: Letters from Alexander Shand to Stephenson Percy Smith transcribed by unknown

Reference number: MS-0850

Iwi/hapū:

Moriori*

General*

Keywords:

Māori Language - Grammar

Abstract: Stephenson Percy Smith $(1840-1922)$ was popularly known as S. Percy Smith. He was English born and came to New Zealand with his parents at the age of 9. Smith was a surveyor and public servant but probably best known as an ethnologist and writer. This item includes a number of letters from Shand describing differences between the Māori and Moriori languages.

100

Collector: Unknown

Year: n.d.

Title: Maori language lessons book

Collection Title: Maori language lessons book

Reference Number: MS-0914

Iwi/hapū:

General

Keywords:

Māori Language - Glossaries, vocabularies, etc

Māori Language - Grammar

Papakupu

Wetereo

Abstract: This notebook contains vocabulary lists for Te Paipera Tapu (The Holy Bible). It covers vocabulary from the book of Mark, chapters IV to VIII. Numbers in the margins are verse numbers. The second part of the item is titled 'Mr Fletcher's Lessons I - IV'.

101

Collector: Wilkinson, George Thomas

Year: $1871-1886$

Title: Acts of parliament and related papers, mostly in Maori

Collection Title: Papers relating to George Thomas Wilkinson (MS-1014)

Reference Number: MS-1014/017

Iwi/hapū:

General

Keywords:

Legal documents 
Abstract: This item contains Acts written in Māori, including Te Ture Whenua Maori 1886, Te Ture Whakahaere nga Whenua Maori, Te Ture Kooti Whenua Maori, Te Ture Whakamana Karaati Rahui 1886.

102

Collector: Wilkinson, George Thomas

Year: 1892

Title: Notes and lists of points relating to land formerly occupied by Ngati Raukawa

Collection Title: Papers relating to George Thomas Wilkinson (MS-1014)

Reference Number: MS-1014/023

Iwi/hapū:

Keywords:

Ngāti Raukawa

Ngāti Maniapoto

Legal documents

Abstract: Thomas George Wilkinson (1845 - 1906) was a surveyor, interpreter and land purchase officer in Thames/Coromandel. This item contains notes from the Māori Land Court about a dispute over land between several hapū of the Otorohanga region.

103

Collector: Gilfedder family

Year: n.d.

Title: Whakapapa

Collection Title: Gilfedder family: Papers (MS-1077)

Reference Number: MS-1077/187

Iwi/hapū:

Keywords:

$$
\text { Kāi Tahu }
$$

Whakapapa

Abstract: Judge Michael Gilfedder (1865 - 1950) was a school teacher at Wreys Bush in Southland, for ten years, a member of the House of Representatives for Wallace from 1896 to 1902. He then studied for the Bar, being admitted in 1904. He practiced law as a barrister and solicitor in Invercargill until 1907, when he was appointed judge of the Native Land Court. Judge Gilfedder kept his position as judge for 26 years. Various members of the Gilfedder Family were involved in the law and teaching professions. This item contains four whakapapa: by Nohoia Hinepare, concerning Herewini Tutoko; annotated whakapapa of Makapi and Tatopi; and two relating to John Arnett. There is also a note asking the whereabouts of lands belonging to Wharehopu.

104

Collector: Gilfedder family

Year: n.d. 
Title: Whakapapa

Collection Title: Gilfedder family: papers (MS-1077)

Reference Number: MS-1077/250

Iwi/hapū:

Te Arawa (?)

Keywords:

Whakapapa

Abstract: This item comprises an extensive whakapapa headed 'Tarawera whakapapas'.

105

Collector: Hamlin, James

Year: 1860-1864

Title: Letters to Hamlin from Maori

Collection Title: Collected papers of and relating to Reverend James Hamlin (ARC-0424)

Reference Number: MS-1209/004

Iwi/hapū:

Taranaki*

Ngāti Hauā*

General*

Keywords:

Letters

Abstract: James Hamlin was born in England and came to the Bay of Islands with his wife Elizabeth and William Williams, in 1826. He was stationed at Waimate, and later Kerikeri, as a lay teacher for the Church Missionary Society. In 1844 he was ordained deacon and sent to Wairoa, Hawkes Bay. This item contains a large number of letters in Māori written by various Māori to Reverend Hamlin. Correspondents include: Ngariki, Te Aotea, Toha, Aihepene Kaihau, William Tamihana Te Waharoa, Hunia Haere and Te Paratene (? Ngata, or? Turangi).

106

Collector: Marsden, Samuel

Year: 1825

Title: Letter to Samuel Marsden from the Maori Chief Rawiri Taiwanga

Collection Title: Collected papers of and relating to Reverend Samuel Marsden (ARC-0001)

Reference Number: MS-2267/004

Iwi/hapū:

Keywords:

$$
\text { Ngā Puhi* }
$$

Letters

Abstract: Samuel Marsden (1765 - 1838) was born in England and spent a number of years as a chaplain in Sydney before coming to New Zealand in 1809 to establish a mission in the bay of Islands. This item is a letter from Ngā Puhi chief Rawiri Taiwanga to Reverend Marsden requesting nails to help build a house and discussing his missionary work. 
Collector: Parata, Hoani

Year: 1910

Title: 'Hinemoa, with notes and vocabulary' by Rev. H.J. Fletcher

Collection Title: Parata, Hoani, Canon: papers (ARC-0433)

Reference Number: MS-2430

Iwi/hapū:

General

Keywords:

Māori Language - Glossaries, vocabularies, etc

Māori Language - Grammar

Papakupu

Wetereo

Narrative

Abstract: Hoani Parata was born in 1881 at Puketeraki, the son of Teone Parata and grandson of Tame Parata. He was ordained deacon in 1907 and priest in 1908. He was later made a canon of the Cathedral and represented the Diocese on General Synod, the first Maori priest to do so. This item is a text book by Rev. Fletcher comprising a narrative of the story of Hinemoa and Tutanekai with notes and vocabulary.

\section{8}

Collector: Piki, Te

Year: 1882-1883

Title: Te Piki: Letters, 13 September 1882 - 16 December 1883 from Whakatangi.

Collection Title: Te Piki: Letters, 13 September 1882 - 16 December 1883 from Whakatangi.

Reference Number: MS-2512

Iwi/hapū:

Keywords:

Ngāti Hauā (?)

\section{Letters}

Abstract: This item is a collection of letters from Whakatangi to Te Piki. Te Piki is residing at Puketata in the Hauraki, and Whakatangi at Arekahanara (now known as Pirongia). Whakatangi is also from Puketata but in Arekahanara due to work commitments. It is obviously a close relationship.

109

Collector: Hocken, Thomas Morland, Dr

Year: n.d.

Title: 'Maori Airs'

Collection Title: Hocken, Thomas Morland, Dr: Papers (ARC-0180)

Reference Number: MS-2522

Iwi/hapū: 


\section{General* \\ Keywords: \\ Waiata}

Abstract: Dr. Thomas Morland Hocken (1836 - 1910) was a doctor, historian, collector and bibliographer. His collection of books, manuscripts, and artifacts formed the basis for the Hocken Library (now known as the Hocken Collections). This item is a single sheet containing a waiata. The composer and $i w i$ of origin are unknown. 


\section{Appendices}

\section{Keyword index}

Occurrences are identified by bibliographic item number.

Haka

$4,16,18,22,28,30,37,89,95$.

\section{Karakia}

$1,2,3,9,10,14,16,18,22,26,28,36,44,87,92$.

\section{Karanga}

28.

\section{Legal documents}

$31,91,101,102$.

\section{Letters}

$4,7,8,11,20,21,22,23,24,25,27,29,31,34,35,38,45,46,47,91,93,94,105$, $106,108$.

Māori language - Glossaries, vocabularies, etc

$5,10,12,13,14,17,18,19,22,28,29,31,40,41,43,47,60,69,77,78,86,88,99$, $100,107$.

Māori language - Grammar

$5,6,17,18,22,26,31,100,107$.

Māori language - Pronunciation

$5,6,17,28,51,52,64$.

Names

34.

Narrative

$1,2,3,9,10,15,16,17,18,21,22,24,30,36,39,44,47,65,71,72,85,90,92,94$, 96, 107.

\section{Papakupu}

$5,10,12,13,14,17,18,19,22,28,29,31,40,41,43,47,60,69,77,78,86,88,99$, $100,107$.

\section{Place names}

$33,48,50,52,53,54,55,56,57,58,59,60,61,62,63,65,66,67,68,69,70,71,72$, $73,74,75,77,78,81,88$. 


\section{Waiata}

$2,3,4,10,15,16,18,19,22,24,26,28,29,30,34,35,36,38,42,48,71,72,88,89$, $95,98,109$.

\section{Wetereo}

$5,6,17,18,22,26,31,100,107$.

\section{Whaikōrero}

$11,19,27,30,45,46$.

\section{Whakahua}

$5,6,17,28,51,52,64$.

\section{Whakapapa}

$1,2,3,9,10,17,18,20,21,22,26,29,30,34,35,36,37,42,48,76,77,79,80,81$, $82,83,84,90,92,103,104$.

\section{Whakataukī}

$1,4,10,16,18,19,28,34$. 


\section{Iwi/hapū index}

Occurrences are identified by bibliographic item number.

\section{General}

$1,3,5,6,9,10,12,13,14,15,16,22,26,27,28,29,30,32,33,37,60,64,69,78$, $86,93,95,96,98,99,100,101,104,107,109$.

\section{Kāi Tahu}

$10,17,20,39,40,41,42,43,44,45,46,47,48,49,50,51,52,53,54,55,56,57,58$, $59,60,61,62,63,65,66,67,68,69,70,71,72,73,74,75,76,77,79,80,81,82,83$, $84,85,88,90,91,96,97,103$.

\section{Kāti Huirapa}

42.

\section{Kāti Irakehu}

79.

\section{Kāti Kuri}

39,42 .

\section{Kāti Mamoe}

$39,42,45,46,65,77,81,82,84,88,90,91,96$.

\section{Kāti Tuhaitia}

47.

\section{Mataatua}

21.

Moriori

99.

\section{Muaūpoko}

34.

Ngā Māhanga

21.

\section{Ngā Puhi}

18, 21, 25, 31, 36, 106.

\section{Ngāi Te Rangi}

$16,18,19,20,23,24,36$.

\section{Ngāi Tumatakokiri}

24.

Ngāti Awa

$4,21,24,26,36,94$. 
Ngāti Hauā

$2,11,18,22,23,27,28,30,37,105,108$.

Ngāti Ira

98 .

Ngāti Kahungunu

$10,19$.

Ngāti Koi

37.

Ngāti Mahuta

20.

Ngāti Maniapoto

11, 22, 102.

Ngāti Maru

2,36 .

Ngāti Paoa

4, 24.

Ngāti Porou

29, 92, 98 .

Ngāti Rangatahi

25,34 .

Ngāti Ranginui

$16,23,30$.

Ngāti Rangiwewehi

$38,94,95$.

Ngāti Raukawa

$10,19,24,30,35,102$.

Ngāti Tama

25,34 .

Ngāti Tamatera

9, 16, 24.

Ngāti Te Upokoiri

10. 
Ngāti Toa Rangatira

$3,4,10,11,22,24,25,28,34,38,39,95$.

Ngāti Tūwharetoa

$23,36,95$.

Ngāti Whakaue

$11,30,34,36$.

Ngāti Whātua

$9,11,36$.

\section{Pākehā}

$8,16,20,21,25,27,30,31,34,94,96$.

\section{Rarawa}

$22,36$.

\section{Rongo-whakaata}

4.

\section{Taranaki}

29, 34, 87, 94, 105.

Te Arawa

1, 2, 4, 7, 10, 18, 21, 22, 34, 35, 95, 104.

Te Āti Awa

$34,95$.

Te Aupouri

22.

Te Roroa

93.

Te Whakatohea

36, 94.

Tuhourangi

34.

\section{Waikato}

11, 18, 19, 20, 22, 23, 24, 27, 29, 35, 36, 37, 38.

Waitaha (Te Arawa)

24. 
Waitaha (Te Waipounamu)

$44,48,65,76$.

Whanganui

88. 